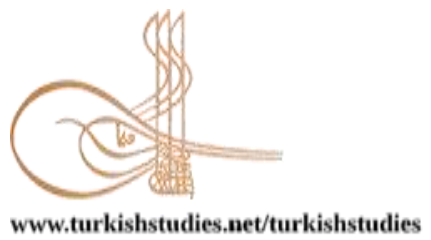

Turkish Studies

\title{
Basında Hegemonik Söylem: Andrew Craig Brunson Krizi Örneği (Siyasi İktidar ile Sabah İnternet Gazetesinin Andrew Craig Brunson'un Tutuklanması ve Salıverilmesi Süreçlerinde Geliştirdiği Söylemlerin Karşılaştırılması)
}

\author{
Hegemonic Discourse In The Press: Andrew Craig Brunson Crisis Example (Comparison of the \\ Statements Developed by the Government and the Sabah Internet Newspaper in the Process of the \\ Arrest and Release of Andrew Craig Brunson)
}

\author{
Samed Soy ${ }^{*}$ - Yılmaz Türker Sandıkcı**
}

\begin{abstract}
In recent years, it has been observed that there is a parallel between the news production contents of some print or visual media outlets and the discourse of the ruling political power. The communication strategies developed by the ruling power based on incidents and facts on the agenda are reflected in the way some media organizations convey their news. Therefore, how such media outlets present the news is based on the discourse of the ruling power, and this becomes a confirmation of the ruling power's actions, decisions, and statements. From this point of view, the parallel between Andrew Brunson's arrest process and the discourse of the ruling power and the way this discourse was reflected in the media was considered worth examining. In this context, the newspaper Sabah, which belongs to the Turkuvaz Media Group, which is known for its relative affinity to the ruling power in terms of content production and presentation, and which had the highest circulation at that time, was included in the study. Within the scope of the critical discourse analysis of van Dijk, the newspaper was subjected to a comparative analysis of the approach of the ruling power to the incident and the newspaper's news presentation. In the context of the critical discourse method of van Dijk, the discourse of the ruling power and the way it reflected on the news were analyzed under the subheadings of news headlines, news entries, photographs, presentation of the main incident, background and context information, results, news sources and the assessments of the parties in the incident which are in a macrostructure and syntactic analysis, local coherence, word choices and news rhetoric which are in a microstructure. Accordingly, the differentiation of the ruling power's discourse during the periods of arrest and release of Andrew Brunson and the reflection of this differentiation on the news content production of the online newspaper Sabah were examined. The negative discourse developed by the ruling power during the arrest and post-arrest period of Brunson and the softening of the discourse along with the release process remained in parallel with their reflections on the newspaper news content. Both the negative approach of the ruling power to the incident in the first period and the way the
\end{abstract}

\footnotetext{
* Doktora Öğrencisi, Süleyman Demirel Üniversitesi, Sosyal Bilimler Enstitüsü, Halkla İlişkiler ve Tanıtım Anabilimdalı PhD Student, Süleyman Demirel University, Graduate School of Social Science, Public Relations and Publicity Department ORCID 0000-0002-4664-2717 samedsoy@ outlook.com

** Doktora Öğrencisi, Süleyman Demirel Üniversitesi, Sosyal Bilimler Enstitüsü, Halkla İlişkiler ve Tanıtım Anabilimdalı PhD Student, Süleyman Demirel University, Graduate School of Social Science, Public Relations and Publicity Department ORCID 0000-0001-8318-7218

turksanyts@gmail.com

Cite as/ Atıf: Soy, S. \& Sandıkcı, Y. T. (2020). Basında hegemonik söylem: Andrew Craig Brunson krizi örneği (siyasi iktidar ile Sabah internet gazetesinin Andrew Craig Brunson'un tutuklanması ve salıverilmesi süreçlerinde

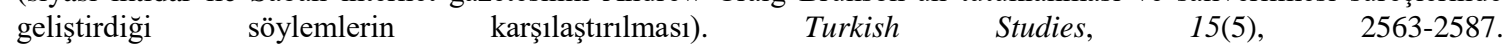
https://dx.doi.org/10.7827/TurkishStudies.44255

Received/Geliș: 16 June/Haziran 2020

Accepted/Kabul: 25 August/Ağustos 2020

Copyright $($ ) MDE, Turkey

Checked by plagiarism software

Published/Yayın: 31 August/Ağustos 2020

CC BY-NC 4.0
} 
online newspaper Sabah conveyed the incident occurred similarly, and in the second period that came forth with the release of Brunson, it was determined that the newspaper created news content in line with the softening discourse of the ruling power. In the comparative analysis carried out within this framework, the discourse of the people who shape the society, which is the ruling power, and online newspaper Sabah's news presentation showed a qualitative similarity, and this situation revealed the reflection of a hegemonic discourse to the media.

Structured Abstract: Introduction: In the study, based on the assumption that there is a hegemonic discourse in the Turkish press, to present this discourse, the online newspaper Sabah, which ranks first in the circulation rankings of online newspapers of the period and is known for its relative affinity to the ruling power was closely examined in the scope of news content production and presentation styles, specifically in the case of Andrew Brunson which is considered as a crisis for Turkey. Accordingly, the discourses developed by the ruling power during the periods of arrest, trial, and release of Brunson and the news content and presentation styles produced by online newspaper Sabah during these periods were subjected to a comparative analysis.

\section{The Importance of The Study}

Many studies examine the issues related to the reflection of the discourses of the ruling political power to the media in different aspects. These consist of works carried out under these titles: Media on the Axis of Political Ideology and Manipulation: 16 April 2017 A Critical Discourse Analysis of the Media Reflections of the Referendum, Political Segregation And Media in Turkey: The Analysis of the Presentation of the February 28 Process in the Central Media with Critical Discourse Analysis, A Review on the Discourses of the Issue of Democratic Initiative Reflected by the Print Press, Reading Representative Examples of Turkish-Israeli Crises in Turkish Media with Fairclough's Discourse Analysis, Israel's Marginalization Policy Through Media in the Context of Political Discourse, Review of the Print Press in Terms of Political Communication in Turkey in the 2011 General Elections Process, Analysis of Propaganda Speeches of Presidential Candidates with Van Dijk's Discourse Analysis Method, Political Discourse's Changing and Unchanging Value Priorities in Turkey: A Value Analysis of 2002, 2007 and 2011 Election Discourses, Presentation of 16 April 2017 Referendum in Newspaper Headlines: With Hürriyet, Sabah, Sözcü and Posta Examples, Media Language and Erdoğan's Speech in Strasbourg and A Discursive Analysis of the Representation of Ahmet Davutoğlu in the Turkish Press in the Elections of 1 November 2015. However, this research has importance as it is the only study examining the news content production and presentation styles of online newspapers in the scope of the Andrew Brunson crisis in the context of van Dijk's discourse analysis, presenting a holistic review based on the data obtained from relational surveys based on the general survey model and conveying original information by subjecting the discourses of the ruling power of the period and the news production and presentation styles of the online newspaper Sabah.

\section{Method}

The research involves the analysis of one of Turkuvaz Media Group's publications, known for its affinity to the ruling political power, and the news published about Andrew Brunson between 11.12.201618.10.2018 on the website of Sabah, which was ranked the first newspaper in circulation rankings, in the context of critical discourse analysis of van Dijk. In the aforementioned date range, Brunson was arrested on 9.12.2016 and released on 12.10.2018, and the period after this date was the second term, the discourse of the ruling power and the news content and presentation styles of the online newspaper Sabah over these two periods were analyzed comparatively. While analyzing these two terms comparatively, Van Dijk's critical discourse analysis model was used. Critical discourse analysis is a method that aims to analyze the political, economic, social, and cultural dynamics of the society, to reveal the background structure of discourse, and to reveal how the existing power/ruling power relations are reproduced in discourse (Karaduman, 2017: 38). According to van Dijk, the discourse analysis whose essence is constituted by the discourse symbolizes a theoretical and methodological approach to language and the use of language. In this framework, articles, speeches, dialogues, and news are the topics that make up discourse analysis (van Dijk, 1988: 24). Van Dijk approaches the discourse analysis process in a structure that separates it as macro and micro. The macrostructure is thematically and schematically divided into two. The thematic structure is composed of news headlines, news entry, spots, and photographs, while the schematic structure is composed of the presentation of the main incident, background information, and news sources (Karaduman, 2017: 40). The microstructure is composed of syntactic analysis, local coherence, word choices, and rhetoric (Doruk, 2013: 115-116). In this context, the 
main reason that Van Dijk's critical discourse analysis model was chosen as the research method is that the model is a method that can reveal hegemonic discourse in the press.

\section{Research Findings}

Within the scope of the research, a total of 48 news pieces were examined. 42 of these reports are from the first period when Brunson was arrested and released, and 6 from the second period, which covers the judicial process and the aftermath. Within the scope of Van Dijk's discourse analysis model, the following consistent and complementary findings were obtained:

In terms of news headlines: The news headlines published in the online newspaper Sabah about Brunson were examined as two periods, the period when Andrew Brunson was arrested and released, and the period after his release. In this context, it was determined that during the period when Brunson was arrested and released, there were 42 news headlines about Brunson, and 6 news headlines during the judicial process and after he was released. The news headlines used in the news articles of the newspaper Sabah, which describes the incidents from the arrest of Andrew Brunson on December 9, 2016, to the trial period he was released, reflect the main theme of the news. The theme was formed over the claim that "Brunson had a role in terror acts in Turkey through terrorist organizations of FETÖ and PKK and the incident became global because of the fact that Brunson is a USA citizen." When the judicial decision of the last court Andrew Brunson was on and the news headlines after he was released were examined, it was written with an objective discourse on the newspaper that Brunson was brought to court, that the court officially announced the judicial decision about Brunson and that Brunson was released. It was observed when the news headlines were examined that the online newspaper Sabah differentiated significantly in these two periods, in which Brunson was arrested and released and after the judicial decision announcement of his release and the period after it. In the first period, there was a news content production related to charges against Brunson related to FETÖ membership, his FETÖ and PKK association, his role in various terrorist acts and many different crimes. However, when the judicial decision of Brunson's release and the news headlines after the release were examined, Brunson was not charged with any crime by the newspaper and there was no mention of intensely developed headlines that previously associated him with terrorist organizations. In this period, only news content production such as "Pastor Brunson and Priest Brunson" was developed, and Brunson was accepted as innocent and free of guilt with the latest published news.

In terms of news entries: As in the news headlines, the discourse in both periods in the news entries differentiated quite differently. In the news entries, until Brunson was released, it was reported that he was associated with FETÖ and PKK in an accusatory and disrespectful manner. After the release of Brunson by judicial decision, the statements of a retired judge who was a victim of FETÖ were included in the news entries and an opposite discourse was formed.

In terms of photographs: The photographs of Andrew Brunson published in the first period were associated with terrorism and the court, and in the second period, the photographs of his meeting with the President Trump of the United States of America at the White House while smiling with his wife were shown. At this point, it was determined that the photographs which were shown act in parallel with the discourses developed by the ruling power in both periods and that they differ periodically.

In terms of the presentation of the main incident and its consequences: Even though there was not a final decision about Brunson by the judiciary in the first period, the online newspaper Sabah gave the verdict that Brunson played a role in various acts of terrorism in Turkey by associating Brunson with FETÖ and PKK. In the following period, as a result of the decision to release Brunson by the judiciary, by reflecting the opinion of a person who was described as a FETÖ victim and a retired military judge to its news content, stated that the decision was correct by using that person. When these two results were taken into consideration, it was revealed that the online newspaper Sabah did not act objectively in terms of news content and presentation.

In terms of background and context information: When the news was examined, it was observed that there was not enough background and context information. In this context, Brunson was the subject of the news claiming that he had an association with FETÖ and PKK after the period that started with the coup attempt of the Fethullah Terrorist Organization (FETÖ) on 15 July 2016. There was no news about him before.

In terms of news sources and assessments of the parties of the incident: NTV (Nergis Television), İHA (İhlas News Agency), DHA (Demirören News Agency), AA (Anadolu Agency) and the newspaper Yeni 
Asir were mostly the sources of the analyzed news. It appeared that the newspaper Sabah preferred to use a biased language in news content production until Andrew Brunson was released after his arrest. However, it was observed that after the judicial process in which Andrew Brunson was released, the online newspaper Sabah abandoned the accusatory language use and started to convey the incidents impartially. In the news content published in this framework, Brunson's release status was reported with a direct quote from a person portrayed as a witness.

In terms of syntactic analysis: When the sample articles published before and after the mentioned comparison were examined, the incidents were given with an active structure. The main subject of the incident was Andrew Brunson, and in the news articles, Andrew Brunson was often presented as an active subject. As a sentence structure, mostly regular and sequential sentences were preferred.

In terms of local coherence: It was determined that in the news articles published in the first period, a narrative based on a causal and functional association stood out and in the second period, a narrative based on a referential association stood out.

In terms of word choice: In the news articles published in the online newspaper Sabah in the first period, Andrew Brunson was generally associated with terrorist organizations FETÖ, PKK, and PYD, also the words the USA citizen and the FETÖ member words were used to describe him in various news. During this period, the adjectives Priest and Pastor were also used, though to a lesser degree. In the second period, the names of the terrorist organizations mentioned were not included in any way, and it was observed that only the adjectives of Pastor and Priest were used when talking about him. When these two periods are compared, it is striking that there is a significant difference in word choices.

In terms of news rhetoric: In both periods, Brunson's ordinary photographs and photographs of him with his wife were included. However, photographs of the terrorist organization PKK militants, FETÖ leader Fethullah Gülen and President of the United States of America Donald Trump were added to the photographs of Brunson with Photoshop in the first period. This was done to support the claim that Brunson had an association with terrorist organizations. At the same time, Trump's inclusion in the photographs aimed to create the impression that he was involved in the process.

\section{Result}

In the light of this process, the fact that the discourses of the ruling political power differentiated and that this reflected to the newspaper's news content and presentation styles reveals that this reflection was in accordance with the current hegemony. This differentiation in particular with the Andrew Brunson incident enabled us to reach conclusions that support the existence of a hegemonic discourse in the press.

Keywords: Communication Sciences, Hegemonic Discourse, Critical Discourse Analysis, Sabah Internet Newspaper, The Rhetoric of Power, Andrew Craig Brunson, News Presentation Formats

Öz: Son yıllarda yazılı ya da görsel bazı medya organlarının haber üretim içerikleri ile siyasi iktidarın söylemleri arasında paralellik olduğu gözlemlenmektedir. İktidar sahiplerinin gündemde yer alan olay ve olgular bazında geliştirdikleri iletişim stratejileri birtakım medya kuruluşunun haber aktarma biçimine yansımaktadır. Dolayısıyla bu tür medya organlarının haber sunuş biçimleri iktidarın söylemleri üzerinden oluşarak iktidarın eylemlerini, kararlarını ve ifadelerini tasdik edici bir hal almaktadır. Buradan hareketle çalışmada, ülkemiz bazında Amerika Birleşik Devletleri’yle bir kriz boyutuna varan Andrew Brunson’un tutuklanma süreci ve sonrası iktidarın söylemleri ile bu söylemlerin medyaya yansıyış biçimleri arasındaki paralellik incelenmeye değer görülmüştür. Bu bağlamda haber içerik üretim ve sunuş biçimleri açısından dönemin internet gazete tirajı sıralamasında ilk üçte, nispeten iktidara yakın olması konumunda ise birinci sırada yer alan Sabah internet gazetesi araştırmaya dahil edilmiş, van Dijk'ın eleştirel söylem çözümlemesi kapsamında iktidarın olaya yaklaşımı ve gazetenin haber sunuş biçimi karşılaştırmalı bir analize tabi tutulmuştur. Van dijk'ın eleştirel söylem yöntemi minvalinde iktidarın söylemleri ve habere yansıyış biçimleri makro yapı içerisinde bulunan; haber başlıkları, haber girişleri, fotoğraflar, ana olayın sunumu, ardalan ve bağlam bilgisi, sonuçlar, haber kaynakları ile olay taraflarının değerlendirmeleri, mikro yapı içerisinde ise yer alan sentaktik çözümleme, bölgesel uyum, sözcük seçimleri ve haber retoriği alt başlikları altında çözümlenmiştir. Bu doğrultuda Andrew Brunson'un tutuklanma ve serbest bırakılma dönemlerinde iktidarın söylemlerinin farklılaşması ve bu farklılaşmanın sabah internet gazetesi haber içerik üretimine yansıması

Turkish Studies, 15(5) 
mercek altına alınmıştır. Brunson'un tutuklanma ve sonrası aşamasında iktidarın geliştirdiği olumsuz söylemler ile serbest bırakılma süreciyle beraber bu söylemlerin yumuşaması gazete haber içeriklerine yansımaları açısından aynı paralelde seyretmiştir. İktidarın ilk dönemde olaya olumsuz yaklaşımı ile Sabah internet gazetesinin olayı aktarış biçimi benzer şekilde vuku bulmuş, yine aynı zamanda Brunson'un serbest kalmasıyla birlikte ortaya çıkan ikinci dönemde iktidarın yumuşayan söylemleri paralelinde gazetenin haberi sunduğu tespit edilmiştir. Bu çerçevede gerçekleştirilen karşılaştırmalı analizde topluma yön veren kesimin yani iktidarın söylemiyle Sabah internet gazetesinin haber sunuş biçimi niteliksel açıdan benzerlik göstermiş ve bu durum hegemonik bir söylemin medyaya yansımasını ortaya çıkarmıştır.

Anahtar Kelimeler: İletişim Bilimleri, Hegemonik Söylem, Eleştirel Söylem Analizi, Sabah İnternet Gazetesi, İktidarın Söylemleri, Andrew Craig Brunson, Haber Sunum Biçimleri

\section{Giriş}

İnsanlığın doğuşuyla beraber başlayan iktidar mücadeleleri gelişen ve değişen teknolojik ilerlemeler sayesinde uygulanış biçimindeki farklılıklarla günümüze kadar sürmüştür. Dolayısıyla, devlet toplum ilişkilerinin başlaması sistem arayışlarına yol açmış en nihayetinde günümüz açısından geçerliliği dünyada en çok kabul gören demokratik sisteme geçiş sağlanmıştır.

Demokratik sistemlerde yöneticiler yapılan seçimlerle halk tarafindan belirlenmekte ve meşruiyetini bu şekilde kazanmaktadır. Ancak iktidarı elinde bulunduranlar ya da iktidara talip olanlar halkın tercihlerini etkilemek için kendi düşüncelerini, vaatlerini, ideolojilerini aslında halkın düşünce, vaat ve ideolojileri şeklinde sunma çabası içerisine girer ve bu doğrultuda hegemonik bir söylem geliştirirler. Bu söylemlerin geniş kitlelere ulaşması gerekliliği egemen güçlerin ve iktidara talip olanların medya ile olan ilişkilerini biçimlendirmektedir. Katılımcı demokratik sistemlerin varlığını sağlıklı bir şekilde sürdürebilmesi hegemonyanın etkin ve sürekli bir şekilde sağlanabilmesiyle mümkündür. Çünkü günümüzde baskı, şiddet ve korkuya dayalı bir sistemin varlığını sürdürmesi mümkün değildir. Ancak halkın rızasını alan, halkı razı edebilen bir iktidar ve sistem mevcudiyetini devam ettirebilir. Bunun gerçekleşebilmesinde ise medya çok önemli bir işleve sahiptir. Bu bağlamda topluma yön veren iktidarlar, kendi düşüncelerini halkın düşüncesiymiş gibi yansıtabilmek için medyayı oldukça etkili bir araç olarak kullanır ve bu sayede büyük çoğunluk azınlıklar tarafından razı edilerek iktidar sürekli olarak yeniden üretilir.

Tarihsel süreç içerisinde gazeteciliğin temelleri batı geleneğinde oluşmuş buradan da tüm dünyaya yayılmıştır. Ülkemizde ise siyasal içerik üretimi anlamında gazeteler ve gazeteciler Osmanlı ile birlikte hayatımızdaki yerini almıştır. Cumhuriyetin ilanıyla beraber oluşan tek parti dönemi ve daha sonraki yıllarda geçilen çok partili sistemde de gazetecilik anlayışı varlığını sürdürmüş ve günümüze değin ulaşmıştır. Basın yayın organlarının içerik üretimleri özellikle 1980'li yıllarla birlikte liberalleşme sürecine paralel olarak farklılaşmış, güç ve iktidar ilişkileri çerçevesinde şekillenmeye başlamıştır. Medyanın sahiplik yapısının evrimi basın alanındaki kısıtlı sermaye yerine farklı sektörlerden yatırımcıların basın yayın araçlarına sahip olmasını sağlamış bu durum ise medyanın endüstrileşmesine neden olmuştur. Bu endüstrileşme Osmanlı'dan bu yana var olan siyasal amaç ve faydalar için gazetecilik geleneğini pekiştirmiştir. Bu minvalde gazeteler, iktidarlarla kurdukları iletişim sürecinde bir güç olarak kullanılmıştır. İktidarlarla kurulan güç ve denge ilişkileri ise gazeteciliğin eksenini kaydırmış; gazetelerin ve gazetecilerin tarafsı/dengeli bir habercilik yapmasını zorlaştırmış aynı zamanda gazeteleri ve gazetecileri siyasal amaçlara hizmet eder bir unsur haline getirmiştir.

Egemen güçlerin hegemonyalarını kurmaları ve bunu devam ettirmeleri için sıklıkla haber medyasının kullanıldığı bilinmektedir. Dolayısıyla, gücü elinde barındıran iktidarlar haber medyalarının içerik üretimlerine birtakım yöntemlerle müdahale edebilmekte, kendi çıkarları doğrultusunda haberleri inşa ettirebilmektedir. Bu işleyişten dolayı medyanın haber üretim ve sunuş biçimleri nesnellikten uzaklaşarak adeta bir iktidar savunuculuğuna dönüşebilmektedir. Son yıllarda kapitalist düzen kapsamında diğer ülkelerde olduğu gibi ülkemizde de haber medyasının gerçekleri 
tarafsız bir biçimde sunacak bir yapıdan giderek uzaklaşması sorunu haberlerin hegemonik söylem üzerinden analiz edilmesi gerekliliğini ortaya çıkarmıştır. Buradan hareketle çalışmaya konu olan olayın öyküsünü özetleyecek olursak; İzmir'de rahip olarak görev yapan ve Amerika Birleşik Devletleri vatandaşı olan Andrew Brunson 9.12.2016 tarihinde gözaltına alınmış ve daha sonra tutuklanmıştır. Yargılama sürecinin başlamasıyla beraber Brunson'un FETÖ, PKK gibi terör örgütleriyle ve çeşitli terör eylemleriyle ilişkili olduğu iddiasıyla tutukluluğu devam etmiştir. Yaşanan bu durumlar Amerika Birleşik Devletleri ve Türkiye arasında bir gerilime neden olmuş, Amerika Birleşik Devletleri Başkanı Donald Trump Brunson'un serbest bırakılmasını istemiş, serbest bırakılmaması durumunda ise Türkiye'ye yönelik birçok ekonomik yaptırımın gerçekleştirilebileceğini belirterek Türkiye'yi alenen tehdit etmiştir. Türkiye tarafinda ise başta Cumhurbaşkanı Recep Tayyip Erdoğan olmak üzere bazı üst düzey yetkililer Brunson'un bağımsız Türk mahkemeleri tarafından yargılandığını belirterek Brunson'a yönelik suçlayıcı bir söylem geliştirmişlerdir. Diğer bir yandan FETÖ lideri Fethullah Gülen'in ABD'de yaşamasına rağmen hem yargılanmamasına hem de Türkiye'ye yargılanmak üzere istenmesine rağmen iade edilmemesine tepki gösterilmiştir. Bütün bu süreç sonunda ikili ilişkiler sonucunda ortaya çıkan kriz durumu Andrew Brunson'un tutukluluk süreci boyunca devam etmiş ve Brunson mahkeme kararıyla 12.10.2018 tarihinde serbest bırakıldıktan sonra sona ermiştir. Yaşanan olaylar 1şı̆ı̆ında iktidar yetkilileri, Brunson'un bağımsız olarak yargılandığı üzerinde durmuş ancak gerçekleştirdikleri söylemleriyle Brunson hakkında bahsi geçen terör örgütlerine üyelikleri olduğu kapsamında olumsuz bir alg1 yaratmaya çalışmıştır. Brunson'un serbest bırakılmasından sonra ise yine yargıya atıfta bulunarak yargının bağımsızlığı ön plana çıkarılmış ancak rahip hakkında olumsuz herhangi bir söylemde bulunulmamıştır.

Hegemonik söylemler 1şı̆̆ında haber içerik ve sunuş biçimlerinin irdelendiği araştırma, üzerinde durulan olayın o dönemde gazete tiraj1 sıralaması açısından birinci olan (http://gazetetirajlari.com, 2016-2018) ve nispeten iktidara yakınlığıyla bilinen Sabah internet gazetesine yansımasını, Brunson'un tutukluluk ve serbest bırakıldıktan sonraki dönemlerinde yapılan haberlerde geliştirilen söylemi ve bu söylemin iktidar söylemiyle paralellik gösterip göstermediğini ortaya koymayı amaçlamaktadır. Bahsedilen bu amaçlara ulaşabilmek için çalışmada yöntem olarak van Dijk'in eleştirel söylem analizi kullanılmış, makro ve mikro yapı incelemeleri sonucu iktidarın her iki farklı dönemde farklılaşan söylemleri kapsamında gazetenin aynı doğrultuda hareket ettiği haber içerik ve sunuş biçimlerinden tespit edilmiştir. Elde edilen bulgular 1şığında; makro ve mikro yapı açısından karşılaştırılan iki dönem arasında önemli ölçüde farklılaşma olduğu görülmüş bu kapsamda basında hegemonik bir söylemin varlığına yönelik güçlü kanıtlar elde edilmiştir.

\section{Eleştirel Ekonomi Politik Bağlamında Medyada Dil ve Söylem}

Ekonomi Politik, tarihsel süreç içerisinde bireylerin ekonomik yaşantılarını devam ettirebilmeleri için gerekli olan mal ve hizmetlerin üretim ve değişimini, bunların kimler tarafından tüketildiğini, sosyal yaşamdaki egemenliği ve mücadeleyi inceleyen bir bilimdir. Ekonomi politik aynı zamanda pazar ekonomisi ve siyasi otorite tarafından üretilen medya içeriklerini, kültürel alandaki üretim ve dağıtım süreçlerini de konu edinmektedir (Yaylagül, 2016: 143-144).

Eleştirel Ekonomi Politik bilimiyle ilgilenenler, medyanın siyasal sistem içerisinde sadece kendi çıkarları doğrultusunda hareket eden büyük şirketlerin tekeline girdiğini, farklı seslerin ortadan kalktı̆̆ını ve bu durumun ise demokrasiye zarar verdiğini ifade etmektedir (Dalgalıdere, 2011: 74). Özellikle bu durum kapitalist sistemlerde çok daha belirgin olarak gözlemlenmektedir. Medyaya sahip olan sermaye sahipleri bir fikrin, görüşün ya da haberin yayınlanıp yayınlanmayacağı, hangi sıklıkla ya da ne şekilde yayınlanacağı konusunda belirleyici rol oynamaktadır (Yaylagül, 2016: 169170). Türkiye'de özellikle 1980'li yılların ikinci yarısında globalleşme girişimleri ile birçok alanda olduğu gibi medya sektöründe de bir değişim meydana gelmiştir. Medya, bu dönemde gazeteci kökenli ailelerin sahipliğinden yavaş yavaş sermayenin sahipliğine geçmiş ve 1990'l1 y1llardan 
itibaren kitle iletişim araçlarının hızlı gelişimi ve yayılımı ile çok kısa bir zaman içerisinde medya, "patron" tarafindan yönetilen sermaye sahiplerinin egemen olduğu bir alan haline gelmiştir (Bulunmaz, 2011: 238). Bu değişim medyanın egemen sınıfın halkla iletişimini sağlayan bir araç olma özelliğini beraberinde getirmiştir. Bu iletişim sürecinde hangi konuların işleneceği kadar bu içeriklerin iletilmesi sürecinde kullanılacak dil ve geliştirilecek söylem de o kadar önemli bir hal almıştır.

Türk Dil Kurumuna göre dil, "İnsanların düşündüklerini ve duyduklarını bildirmek için kelimelerle veya işaretlerle yaptıkları anlaşma ve lisan" (http://www.tdk.gov.tr, 2018) olarak tanımlanmaktadır. Medyada kullanılan dilin, sade ve herkesin anlayabileceği nitelikte olması, gerçek hayattan soyutlanmaması, sokakta konuşulan dilin kullanılması ve hayatı yansıtması gerekmektedir. Fakat medyanın haber verme işlevi göz önünde bulundurulduğunda bu işlev yerine getirilirken dil bilgisi kurallarına uyulması önem arz etmektedir (Yıldız \& Ekin, 2005: 96). Dil açısından medya ve toplum arasında yakın bir ilişki bulunmaktadır. Medya insanların düşünce, tutum ve davranışları üzerinde önemli bir etkiye sahiptir ve bu etkinin oluşmasında ise dilin kullanım biçimi belirleyici unsurlardandır. Dolayısıyla dilin kullanım düzeyinin, biçiminin, nasıl konuşulacağının ve bu kullanım sürecinde hangi sözcüklerin seçileceğinin belirlenmesinde de medyanın belirleyici bir rolü vardır (Çamdereli, 2013: 178).

Söylem (discourse), marksist söylem, kapitalist söylem, ekonomik söylem ve pozitivist söylem gibi ideoloji, ekonomi, bilim, örgüt veya kültürel alanlarda sıkça kullanılan bir kavramdır. (Erdoğan, 2014: 287-288). Söylem dil aracılığıla bilginin üretilmesiyle ilgilidir. Köken olarak söylem, "tutarlı ve akılcı bir konuşma, hutbe ya da yazı" olarak tanımlanmaktadır (Hall, 1992: 201202). Söylem aynı zamanda "dil ya da sözel olmayan işaret sistemleri vasitasılyla kurulan toplumsal iletişim ağlarına da işaret eder". Örneğin; erkeklerin kadınlar için kapı açması, bir restoranda sandalyeye önce kadınların oturması için sandalyenin çekilmesi gibi davranışlar kadınların korunması ve öncelik tanınması gereken canlılar olduğu, erkeklere göre daha zayıf ve hassas oldukları anlamına gelen bir söylemi içermektedir (Purvis ve Hunt, 2014: 21-22). Dolayısıyla her alanın, her davranışın kendine has bir söylemi olduğu gibi medyanın da bir söylemi bulunmaktadır. Medya, topluma hitap eden, topluma kolayca ileti aktarabilen, toplumda davranış değişikliği gerçekleştirme ve toplumu dizayn etme gücüne sahip bir alandır (Yaman ve Durgun, 2017: 41). Günümüzde yadsınamayacak bu gücü elinde bulunduran medyanın kendine özgü bir söylemi vardır. $\mathrm{Bu}$ söylemi kullananlar ise medya mensubu ve gazetecilerdir. Ancak medya mensupları ve gazeteciler söylemleri gerçekleştirirken ya da geliştirirken özgür değildir. Medya mensupları ve gazeteciler egemen sınıfın çıkarını ve iktidarını göz önünde bulundurarak söylemi ortaya koyar ve bu doğrultuda söylem geliştirir (Devran, 2010: 27-28). Devleti yani iktidarı ele geçiren sınıfın hegemonyasını egemen kılmak için güçlü bir iktidara sahip olması gerekir. Bundan dolayı iktidar, egemen sınıf açısından sürekli güçlendirilmesi ve korunması gereken bir kale konumundadır (Çoban, 2013: 31). Dolayısıyla iktidar sahipleri iktidarını tekrar üretip sürdürebilmesi için toplumsal rızayı oluşturmalı ve bunu iktidarın bir aracı haline getirmelidir (Çetin, 2003: 85). Bu bağlamda hegemonya ve iktidar kavramlarının üzerinde durulması önem arz etmektedir.

\section{Hegemonya ve İktidar}

Hegemonya kavramı kültür, iktidar, devlet ve ideoloji kavramlarıyla yakından ilişkilidir. Türk Dil Kurumuna göre hegemonya "bir devletin başka bir devlet üzerindeki siyasal üstünlüğü ve baskısı veya bir kişinin başka bir kişi üzerindeki üstünlüğü ve baskısı" şeklinde betimlenmektedir (http://www.tdk.gov.tr, 2018). Literatürde ise genel anlamda hegemonya, egemen sinıfin çıkarlarının evrensel çıkarlar halinde temsil edilmesi, rızanın imâl edilme süreci ya da zora başvurmadan var olan toplumsal düzeni koruma sanatı (Marshall, 1999: 299-300) olarak aktarılmaktadır. Chomsky ve Herman'a göre (2012: 15) rızanın imalatı sürecinde propaganda önemli bir faktördür. Medya, gücünü elinde bulunduranlar tarafından denetlenen ve finanse edilen bunun 
sonucunda ise bu gruplara hizmet edilen ve onların lehine propaganda yapılan bir alandır. Hegemonyanın sağlanabilmesi zor kullanma ve rızanın aynı anda dengeli bir şekilde yürütülmesi ile mümkündür. Devletin hem içinde hem de dışında kalan alanlarda dağınık ve çelişkili olan iktidar yapısında bir bütünlük ancak bu sayede oluşturulabilmektedir (Şengül, 2015: 52).

İktidar kavramının literatürde birçok tanımı mevcuttur. Genel olarak iktidar, tüm toplumu kuşatan bir ilişki ağı olarak güç ve mülkiyetle ilişkilendirilmekte, bir tarafin iradesini diğer tarafa empoze etme ya da yapmak istemedikleri şeyleri zorla yaptırabilme kapasitesi, (Bâlan, 2010: 38) şeklinde tanımlanmaktadır. Türk Dil Kurumu'na göre ise iktidar "bir işi yapabilme gücü, erk, kudret" (http://www.tdk.gov.tr, 2018) olarak ifade edilmektedir. Yine bir başka tanımda iktidar, elde edilmek istenenlerin sonucunda elde edilen üründür. Yani aynı istekleri bulunan iki taraftan bu istekleri gerçekleştiren taraf iktidarlı taraftır (Russel, 1976: 43).

İktidarın olduğu her yerde hegemonyadan söz etmek mümkündür. Aynı zamanda toplumun olduğu her alanda genellikle bir siyasi iktidarın varlığından söz edilebilmektedir (Çoban, 2012: 2). Örneğin, geleneksel toplumlarda devlet egemen sınıfin kontrolündedir ve egemen sınıf devleti bir araç olarak kullanarak herhangi bir dolaylı yola başvurmadan iktidarını ve hegemonyasını sorunsuz bir şekilde sürdürmüştür. Ancak geleneksel toplumdan modern topluma geçilmesiyle birlikte demokrasinin ortaya çıkması, bireylerin iktidarda temsil edilme talepleri gibi gelişmeler, egemen kesimin sahip olduğu iktidar alanının tartışılmasını sağlamış ve egemenliği elinde bulunduran sınıf için iktidarı toplumla paylaşma riskine neden olmuştur. Dolayısıyla egemen sınıf sahip olduğu iktidarı sürdürebilmesi için modern topluma uygun argümanlar üretmiş ve bu argümanlar sayesinde ellerindeki iktidarı sürdürme çabası içerisine girmiştir. Bu argümanlar; asker, polis, hapishane gibi devletin baskı aygıtlarıyla eğitim, medya, din gibi ideolojik aygıtları içermektedir (Güngör, 2018: 280-281). Bu argümanları kullanarak toplumu yönlendiren ve denetleyen sinıfa "hegemonik grup" denilmektedir (Portelli, 1982:73). İktidarı sağlamak ve sürdürebilmek için hegemonik grubun yani egemen sınıfın kullandığı argümanlar arasında söylem çok önemli bir yere sahiptir. İktidar söylemle elde edilebilecek bir güçtür. Söylem hem bilgiyi hem de iktidarı inşa etmekte, söylemi ise iktidar üretmekte ve yaygınlaştırmaktadır (Güneş, 2013: 61). Bu çerçevede iktidar ile söylem arasında birbirlerini var eden, üreten ve varlığını sürdüren bir bağ ve ilişki söz konusudur.

\section{Bir İktidar Propaganda Aracı Olarak Haber Söylemi}

Haber, "zamana uygun bir şeyin, bir olayın raporudur. Haber bir bilgi iletme hareketidir. Haber insanların kendi yaşamlarını ve toplumdaki konumlarını belirlemeleri, düzenlemeleri ve yönlendirebilmeleri için ihtiyaç duydukları bilgidir" (Çoban, 2013: 44). Farklı bir bakış açısında haber, hegemonyaya sahip güçlerin veya hegemonya üretebilecek potansiyele sahip kesimlerin kendi dünya görüşlerini halka benimsetebilmeleri için yazılı ve görsel olarak kullandıkları iletişim alanıdır.

Medya, elde edilmek istenenlerin elde edilmesi sürecinde çok önemli işleve sahiptir. Medyanın en önemli işlevi bilgi ve haber vermektir. Bu kapsamda medya halkın en önemli enformasyon kaynağı konumundadır. Özellikle günümüzde bu temel işlevi medyanın tarafsız ve doğru bir şekilde yapması beklenmektedir. Ancak iktidar sahiplerinin çıkarlarından ötürü medya, tarafsızlık ve doğruluk ilkesini göz ardı eden, yanlış ve eksik bilgilerle halkı yönlendiren bir araç durumundadır (Mora, 2008: 17). Bunun en büyük nedeni bireylerin haber alma ve bilgilenme süreçlerinde medyaya sıkça başvurması ve medyanın bireyler üzerinde güçlü etkilerinin olmasıdır. $\mathrm{Bu}$ durumun farkında olan iktidarlar genellikle bu mecrayı kontrolleri altında tutmaya çalışmaktadır. $\mathrm{Bu}$ süreçte İktidar sahipleri medya mensuplarına kendi lehlerine olan haberleri veya konuları gündeme taşımaları ve kendi aleyhilerinde olan içerikleri ise gündemden uzak tutmaları konusunda bask1 yapmaktadır (Şimşek, 2009:141). Türkiye'de de durum farklı değildir. Medya, uzun yıllar iktidarın baskısı altında kalmış, iktidar ile medya patronları arasındaki ilişkiler doğrultusunda taraflı bir faaliyet göstermiştir (Sözeri, 2015: 7). 
Medya, hegemonyanın kurulması ve muhafaza edilmesinde en önemli araçlardan biridir. $\mathrm{Bu}$ işi yapanlar ise medya patronlarıdır. Ancak medya patronları bunu gerçekleştirirken kendi inisiyatifleri doğrultusunda değil, iktidar ilişkilerini gözeterek yapmaktadır (Çoban, 2013: 37). Bu sebeple halk medyada gösterilenler karşısında pasif bir durumdadır. İçeriğe müdahale edebilecek bir gücü ve yapısı yoktur. Halka medya karşısında sadece kendisine sunulanlar arasından seçim yapma özgürlüğü verilmektedir (Herman ve Chomsky 2012: 23). Medya tarafindan sunulan bu haber içerikleri ise belirli bir süzgeçten geçtikten sonra halkla ulaşmaktadır. Bu bağlamda haber üretim merkezi olarak adlandırılan medya her yerde egemenlerin kontrolü ve denetimi altındadır. $\mathrm{Bu}$ minvalde hangi konuların haber yapılıp hangilerinin yapılmayacağı, ne şekilde yapılacağ haberde veriliş sıklığı hegemonyaya sahip güçler tarafından karar verilmektedir (Çoban, 2011: 220).

\section{Yöntem}

Araştırma sürecinde elde edilen verilerden tutarlı ve anlamlı bulgular ortaya çıkarmak amacıyla takip edilen yolun analiz edildiği bu başlıkta; araştırmanın gerçekleştirilme amacı, önemi, evreni ve örneklemi, veri toplama araçları ile çözümleme yöntemi ve araştırma soruları yer almaktadır.

\section{Araştırmanın Amacı}

Çalışma, Turkuaz Medya Gurubu'nun yayın organlarından biri olan dönemin internet gazete tirajı sıralamasında ilk üçte, nispeten iktidara yakın olması konumunda ise birinci sırada yer alan Sabah internet gazetesi sayfasında; 11.12.2016-18.10.2018 tarih aralığında Andrew Brunson hakkında yayınlanan haberlerin van Dijk'ın eleştirel söylem analizi bağlamında çözümlenmesini amaçlamaktadır. Bahsi geçen tarih aralığında Brunson'un yakalandığı 9.12.2016 ile serbest bırakıldığg 12.10.2018 birinci dönem ve bu tarihten sonraki süreç ikinci dönem olmak üzere iki döneme ayrılarak veriler toplanmakta elde edilen veriler 1şı̆̆ında her iki farklı dönem içerisinde yayınlanan haberler, iktidarın söylemleri de gözetilerek karşılaştırmalı bir analize tabi tutulmaktadır.

\section{Araştırmanın Önemi}

Siyasal iktidarların söylem analizleri ve hegemonya alanına ilişkin konuları farklı yönleriyle inceleyen birçok çalışma bulunmaktadır. Ancak bu araştırma, Andrew Brunson krizi özelinde internet gazetelerinin haber içerik üretimleri ve sunuş biçimlerini van Dijk'ın eleştirel söylem analizi bağlamında irdeleyen tek çalışma olması, genel tarama modelini esas alarak ilişkisel taramalardan elde edilen veriler doğrultusunda bütüncül bir değerlendirme ortaya koyması ve dönemin iktidarının söylemleri ile Sabah internet gazetesinin haber üretim ve sunuş biçimini karşılaştırmalı bir incelemeye tabi tutarak özgün bilgiler aktarması sebeplerinden dolayı önem arz etmektedir.

\section{Araştırmanın Evreni ve Örneklemi}

Araştırmanın evrenini, Andrew Brunson'un tutuklanması, yargılanması ve serbest bırakılması dönemlerinde internet gazetelerinde yer alan haber içerikleri ve haberin sunuluş biçimleri oluşturmaktadır. Evrenden örnekleme ulaşılması bağlamında, ölçüt örnekleme türü kullanılmıştır. Daha önceden belirlenmiş bir dizi ölçütü karşılayan tüm durumların çalışılmasını içeren bu tarz örneklemede, ölçüt araştırmacı tarafindan oluşturulabilmekte ya da daha önceden hazırlanmış ölçütler listesi kullanılabilmektedir (Marshall \& Rossman'den Akt, Baltacı 2014). Bu kapsamda ölçüt örnekleme türünün tercih edilmesinin başlıca nedeni, Turkuaz Medya Grubu'na ait dönemin internet gazete tirajı sıralamasında ilk üçte, nispeten iktidara yakın olması konumunda ise birinci sirada yer alan gazetenin Sabah internet gazetesi olmasidır.

\section{Veri Toplama Araçları ve Verilerin Analizi}

Araştırma, basında hegemonik söylemi ortaya çıkarmak amacıyla nitel araştırma türlerinden biri olan van Dijk'in eleştirel söylem analizi modeli üzerinde şekillenmektedir. Söylem analizi, metnin sözdizimsel ve semantik sınırlarını aşarak bir yapısöküme uğratma ve o metni üreten tarafın 
asıl niyetini anlama çabasıdır (Solak, 2011: 3). Söylem analizinin odaklandığı ve incelediği en temel unsur dildir (Çelik ve Ekşi, 2008: 105). Eleştirel söylem analizi ise toplumun politik, ekonomik, sosyal ve kültürel dinamiklerini çözümlemeyi, söylemin ardalan yapısını ortaya koymayı, var olan güç/iktidar ilişkilerini söylem içinde nasıl yeniden üretildiğini ortaya çıkarmayı amaçlamayan bir yöntemdir (Karaduman, 2017: 38). Aslını söylemin oluşturduğu söylem çözümlemesi van Dijk'e göre, dil ve dilin kullanımına dair kuramsal ve yöntemsel bir yaklaşımı simgelemektedir. $\mathrm{Bu}$ çerçevede metinler, konuşmalar, diyaloglar ve haberler söylem çözümlemesini oluşturan konulardır (van Dijk, 1988: 24). Van Dijk, söylem analiz sürecini makro ve mikro olarak ayırdığı bir yap1 içerisinde ele alır. Makro yapı kendi içerisinde tematik ve şematik olarak ikiye ayrılmaktadır. Tematik yapıyı; haber başlıkları, girişi, spotlar ve fotoğraflar oluştururken şematik yapıyı; ana olayın sunumu, ardalan bilgisi ve haber kaynakları oluşturmaktadır (Karaduman, 2017: 40). Mikro yap1 ise, sentaktik çözümleme, bölgesel uyum, sözcük seçimleri ve retorik alt başlıkları çerçevesinde anlamlandırılmaktadır (Doruk, 2013: 115-116). Bu minvalde, Amerika Birleşik Devletleri'yle kriz boyutuna varan Andrew Brunson'un tutuklanmas1, yargılanmas1 ve serbest bırakılmas1 dönemlerinde siyasal iktidarın olayla ilgili söylemleri ve nispeten iktidara yakınlığıyla anılan Turkuaz Medya Grubu'na ait Sabah internet gazetesinin 11.12.2016-18.10.2018 tarih aralığında yayınladıkları haber içerik ve sunuş biçimlerine yansımaları karşılaştırılmalı bir analize tabi tutularak anlamlı bulgular elde edilmeye çalışılmıştır. Toplanan veriler doğrultusunda bulgular bütünsel açıdan irdelendiğinde; iktidarın Brunson'un tutuklanmas1, yargılanması ve serbest bırakı1mas1 dönemlerindeki söylemlerinin farklılaşması (olumlu, olumsuz) ve bu söylemlerin Sabah internet gazetesine aynı paralelde yansıması hegemonik söylemin varlığı bağlamında güçlü bir çıkarım yapılmasına olanak sağlamıştır.

\section{Araştırma Soruları}

Araştırma aşağıda yer alan soruları cevaplandırmayı amaçlamaktadır:

Araştırma Sorusu 1: Andrew Brunson'un tutuklu olduğu ve serbest bırakıldığı dönemlerde siyasi iktidar nasıl bir söylem geliştirmiştir ve bu iki dönemde geliştirilen söylemlerde bir farklılaşma var midir?

Araştırma Sorusu 2: Andrew Brunson'un tutuklu olduğu ve serbest bırakıldığı dönemlerde Brunson'la ilgili Sabah internet gazetesinde yayınlanan haberlerde nasıl bir söylem geliştirilmiştir ve bu iki dönemde geliştirilen söylemlerde bir farklılaşma var mıdır?

Araştırma Sorusu 3: Andrew Brunson'un tutuklu olduğu ve serbest bırakıldığ 1 dönemlerde siyasi iktidarın Brunson hakkındaki söylemiyle Sabah internet gazetesinin haber içerik ve sunuş biçimleri arasında bir benzeşme ya da farklılaşma var mıdır?

\section{Bulgular}

Brunson'un Tutukluluk Sürecinde Siyasi İktidarın Söylemleri: Andrew Brunson'un tutuklanmasıyla başlayan ve yargı tarafından serbest bırakılmasıyla sona eren ilk dönemde siyasi iktidarın Brunson'a yönelik suçlayıcı (olumsuz) bir söylem geliştirdiği aşağıdaki metinlerden anlaşılmıştır:

Başkan Erdoğan: Terör örgütleriyle ilişkisi olan bir papaz için Türkiye'yi feda ediyorsun. Sinsi bir oyunla karşs karşıyayız. Oyununuzu gördük ve meydan okuyoruz. Teslim olmayacağız (https://www.sabah.com.tr, 2018).

Erdoğan, söz konusu papazın teslim edilmesini isteyen ABD'ye karşı "Bir papaz da sizde var. Üstelik bizdeki yargılanıyor, sizdeki yargılanmıyor" diyerek tepki göstermişti (https://www.takvim.com.tr/, 2018).

Recep Tayyip Erdoğan: "İsmini andığımız zat, terör örgütleriyle münasebetleri olduğu için tutuklanmıştır. Şu an bu tutukluluk içerisindedir. Sağlık nedeniyle yargı 
kendisinin eve çıkmasına izin vermiştir. 12 Ekim'de mahkemesi var. Mahkemede yargı ne karar verir bunu bilemem. Buna siyasiler de karar veremez. Benzer şeyler özellikle ABD'de olmuş durumda. Örneğin, ABD'de şu anda Türkiye'de 251 kişi, darbe girişiminde bulunan FETÖ ABD'dedir. ABD'de olan bu zat şu an yargılanmıyor. Biz dosyalarını gönderdiğimiz halde, yargılanmamakta buradaki yetkililer ne yazık ki direnmektedir. Türkiye ile $\mathrm{ABD}$ arasında suçluların iade anlaşması vardır. Buna rağmen burada Fethullah Gülen denen şahıs rahatlıkla bırakılabilecekken bırakılmamaktadır. Brunson şu an yargılanmaktadır. Yargılanan bir kişiye bıraktım, git demeye ne ben, ne başkaları yetkilidir. $\mathrm{Bu}$ yetki hakimlerindir. 12 Ekim'de mahkeme ne karar veriri bilemem. 12 Ekim gelsin göreceğiz"( https://www.haberturk.com, 2018).

Brunson'un Serbest Bırakılması ve Sonrası Süreçte Siyasi İktidarın Söylemleri: Brunson'un serbest bırakılmasından sonraki dönemde siyasi iktidar Brunson'a yönelik herhangi bir suçlayıcı (olumsuz) söylemde bulunmadığı gibi bu dönemde yargı bağımsızlı̆̆ı çerçevesinde (olumlu) bir söylem geliştirdiği tespit edilmiştir.

ABD Başkanı Donald Trump, Amerikalı Pastör Andrew Brunson'ın serbest bırakılması sonrası Twitter'dan Cumhurbaşkanı Recep Tayyip Erdoğan'a "yardımı için" teşekkür etti. Erdoğan'ın Trump'a yanıtı ise gecikmedi: "Sayın Başkan, her zaman vurguladığım gibi Türk yargısı kararını bă̆ımsız bir şekilde verdi" (https://www.bbc.com, 2018).

AK Parti Genel Başkan Yardımcısı Hayati Yazıcı, Rahip Brunson'ın serbest bırakılmasıyla ilgili yaptığı açıklamada, "Türkiye'de mahkemeler bağımsız değil' diyenler, yargının bağımsız olduğunu bir kez daha gördüler" dedi (https://www.haberler.com, 2018).

9.12.2016 tarihinde gözaltına alınan ve ardından tutuklanan Andrew Brunson'la ilgili Sabah internet gazetesi ilk haberini 11.12.2016, son haberini ise 18.10.2018 tarihinde yapmıştır. Bu iki tarih aralığında Andrew Brunson'la ilgili gazetede toplam 48 haber mevcuttur. Bunların 42'si Andrew Brunson'un tutuklanıp serbest birakıldığ1 09.12.2016-11.10.2018 tarihleri arasında 6's1 ise 12.10.2018 tarihinde yargılanma aşamasında ve serbest bırakıldıktan sonraki dönemde yayınlanmıştır. Bu haberlerin dağılımları incelendiğinde, Aralık 2016'da 2, Mayıs 2017'de 1, Temmuz 2017'de 1, Ağustos 2017'de 2, Eylül 2017'de 1, Ekim 2017'de 1, Aralık 2017'de 1, Mart 2018'de 11, Nisan 2018'de 7, Mayıs 2018'de 6, Temmuz 2018'de 2, Ağustos 2018'de 4, Ekim 2018'de 9 haber bulunmaktadır. Özellikle 2018 yılının Nisan, Mayıs ve Temmuz aylarında, beraat etme süreci ve beraat ettikten sonraki dönemi kapsayan Ekim (2018) ayında Brunson'la ilgili haberlerin yoğunlaştığı görülmektedir.

\section{Makro Yapı İncelemesi: Tematik ve Şematik Çözümleme}

Tematik Yapı İncelemesi: Bu kısımda, Andrew Brunson'un tutuklanıp serbest bırakıldığı tarih sürecinde ve serbest bırakıldıktan sonraki dönemde Brunson'la ilgili Sabah internet gazetesinde yayınlanan haberlerin başlıkları, giriş cümleleri ve fotoğrafları ele alınmıştır.

Haber Başlıkları: Andrew Brunson'un tutuklanıp serbest bırakıldığı dönem içerisinde Brunson'la ilgili yapılan 42 haber başlığı, serbest bırakıldığı yargılanma süreci ve sonrasında ise 6 haber başlı̆̆ı bulunmaktadır. Bu haber başlıkları şunlardır:

1. İzmir'de Papaza FETÖ tutuklaması

2 Tutuklanan papaz hem FETÖ hem PKK sempatizanı çıktı

3. FETÖ'nün Papazı PYD'li teröristleri kutsamış

4. FETÖ'cü papazın dosyası kabarı çıktı

5. Papaz Brunson 4 kez müebbetle yargılanabilir 
6. FETÖ'cü papaza bir tutuklama daha

7. O papaz hakkında korkunç suçlamalar

8. ABD'li papazın şok ses kaydı ortaya çıtı

9. FETÖ'nün papazı sahte çıktı

10. ABD'li papaz hakkında 35 yıla kadar hapis cezası istemi

11. Trump'ın pastörüne müebbet talebi

12. ABD'li papaz Brunson hakkındaki iddianame

13. ABD'li papaz için 35 yıl hapis istemi

14. ABD'li papaz hakkında hazırlanan iddianame kabul edildi

15. ABD'li papaz Brunson'un 15 Temmuz mesajları ortaya çıktı...

16. Son Dakika: ABD'li papaz ile FETÖ ve PKK'nın hedef birlikteliği iddianamede!

17. Son dakika: Gizli tanık 'Parmaksızlar' listesini ortaya çıkardı!

18. Son Dakika Haberi: Gizli tanık 'Dua' CIA'nın Ankara'daki şefini deşifre etti

19. Son dakika: ABD'li papaz Brunson 16 Nisan'da hakim karşısına çıkacak

20. Diriliş Kilisesi papazı Brunson'un manevi oğlu İzmir'de Kürt kökenli vatandaşları Hristiyanlaştırmak istemiş

21. Papaz Brunson'un FETÖ ile sinyalleri çakıştı

22. Son dakika: ABD'li Papaz Brunson'un yargılanmasına başlandı!

23. Son dakika: ABD'li papaz Brunson mahkemede ağlama krizine girdi

24. FETÖ'nün papazı cevap veremedi

25. Son dakika: Mahkemeden ABD'li rahip Brunson kararı

26. FETÖ'cü senatör papaza koştu!

27. ABD Başkan Yardımcısı Mike Pence'den skandal tweet!

28. Son Dakika: ABD'li papaz yeniden hakim karşısında

29. Son Dakika: Gizli tanıktan ABD'li papaz Andrew Craig Brunsonhakkında flaş ifadeler

30. Trump'ın serbest bırakılmasını istediği papaz Brunson için karar çıktı

31. Hristiyan Kürt Devleti kurmak istiyordu

32. ABD'li rahipten "Rahip Brunson-Fetullah Gülen takası" önerisi

33. Brunson'ın FETÖ'nün üst düzey isimleriyle bağlantıları ortaya çıktı!

34. Son dakika: FETÖ tutuklusu ABD'li rahip Brunson ev hapsine alındı

35. ABD'li rahibe ev hapsi

36. Rahip Brunson'un şifreleri çözülüyor

37. Brunson'un ev hapsine itiraz ikinci kez reddedildi

38. Kobani eylemlerinde Brunson izi

39. Brunson, Suruç saldırısı sırasında Şanlıurfa'daydı 
çıktı

40. Brunson'ın kritik duruşması öncesi gizli tanıklardan yeni iddialar ortaya

41. Rahip Brunson'a mahkeme öncesi kritik ziyaret

42. ABD Büyükelçiliği Maslahatgüzarından Brunson'a ziyaret

Andrew Brunson'un 9 Aralık 2016 tarihinde tutuklanmasından serbest birakıldığ yargılanma sürecine kadarki olayları anlatan Sabah internet gazetesi haber metinlerinde kullanılan haber başlıkları haberin ana temasını yansıtır niteliktedir. Tema "Brunson'un FETÖ ve PKK terör örgütleri aracılığıyla Türkiyede'ki bazı terör eylemlerinde rolünün olduğu ve Brunson'nun ABD vatandaşı olduğu için olayın uluslararası bir boyut kazandığı" üzerinden belirlenmektedir. Habere konu olan olay ve haber teması ana başlıklara bakılarak anlaşılabilmektedir.

Haber başlıklarında görüldüğü üzere, 3, 4, 9 ve 24 nolu başlıklarda Andrew Brunson, FETÖ'cü sıfatıyla nitelendirilmekte ve Brunson'un FETÖ'cü olduğu yargısında bulunulmaktadır. 1, 2, 3, 21, 24, 26 ve 33 nolu başlıklarda Brunson'un FETÖ ile, 2, 3 ve 16 numaralı başlıklarda da PKK ile ilişkisinin olduğuna yönelik malumata yer verilmektedir. 5, 10, 12, 13, 14, 19, 22, 23, 25, 28, 29, $30,35,37$ ve 40 numaralı başlıklarda Brunson'un yargılanmasına yönelik haberler yer almaktadır. 38 ve 39 numaralı başlıklarda Brunson'un Türkiye'de meydana gelen bazı terör eylemleriyle münasebetli olduğu belirtilmektedir. 7, 8, 15, 20 ve 31 numaralı başlıklarda Brunson hakkında çeşitli delillerin ortaya çıktığı ve Brunson'un Türkiye'de gerçekleştirmek istediği amaçlarından bahsedilmektedir. Son olarak 41 ve 42 nolu başlıklarda ise olayın uluslararası bir boyut kazandığından söz edilmektedir.

Gazetenin haber başlıklarını bütüncül bir yaklaşımla değerlendirdiğimizde, Brunson'un tutuklanmasıyla birlikle başlayan süreçte henüz herhangi bir delil ya da yargı kararı ortada yokken gazete Andrew Brunson'u FETÖ'cü ilan etmiş aynı zamanda FETÖ ve PKK terör örgütleri ile olan ilişkilerinden bahsetmiştir. Bunun yanı sıra Brunson'un doğrudan hem FETÖ hem de PKK terör örgütlerinin eylemleriyle ilişkisinin olduğu ifade edilmiştir. Gazete burada tamamen suçlayıcı ve yanlı bir söylem gerçekleştirerek yargı kararı gelmeden harekete geçmiş ve ispat edilmesi gereken suçlamaları haber başlıklarına taşımıştır.

Mahkeme tarafindan serbest birakılan Andrew Brunson'un serbest birakıldığı mahkeme süreci ve serbest kaldıktan sonraki dönemde yayınlanan Sabah internet gazetesi haber başlıkları şunlardır:

\section{Son dakika haberi: Papaz Brunson duruşma için Aliağa’ya getirildi}

44. Son Dakika Haberi: Rahip Brunson hakkında mahkeme kararını resmen açıkladı! Rahip Brunson serbest

45. Rahip Brunson kararı duyunca hıçkırarak ağladı!

46. Brunson Beyaz Saray'da

47. Emekli askeri hâkim Zeki Üçok: Brunson davasında mahkeme hukuka uygun davrand 1

48. Emekli askeri hâkim Zeki Üçok: Brunson davasında mahkeme hukuka uygun davrand 1

Andrew Brunson'un çıkarıldı ğı son mahkemede verilen yargı kararı ve serbest bırakıldıktan sonraki haber başlıkları incelendiğinde, gazete nesnel bir söylemle 43 numaralı başlıkta Brunson'un mahkemeye getirildiğini, 44 numaralı başlıkta mahkemenin Brunson'la ilgili kararını resmen açıkladığını ve Brunson'u serbest bırakıldığını yazmıştır. Özellikle 48 numaralı başlıkta gazete bir emekli hâkimin açıklamasını haberine konu edinerek mahkemenin hukuka uygun davrandığını belirtmiştir. Bu haber başlıklarında herhangi bir olumsuz, suçlayıcı bir söylem bulunmadığı, aksine 
Brunson'un serbest bırakılmasının doğru bir karar olduğu ve olması gerekenin yapıldığı şeklinde bir söylem geliştirildiği görülmektedir.

Sabah internet gazetesinin bu iki dönemin yani Brunson'un yakalanıp serbest bırakıldığı dönem ile serbest bırakıldığı yargı kararı açıklaması ve sonraki dönemde haberleri irdelendiğinde önemli ölçüde farklılaştığı görülmektedir. İlk dönemde Brunson ile ilgili FETÖ'cü, FETÖ ve PKK ile ilişkili, çeşitli terör eylemlerindeki rolü ve birçok farklı suç iddia edilerek geliştirilen bir haber içerik üretimi söz konusudur. Ancak Brunson'un serbest bırakıldığı yargı kararı açıklaması ve serbest bırakıldıktan sonraki dönemde haber başlıkları incelendiğinde, gazete tarafından Brunson'a herhangi bir suç isnat edilmemiş ve daha önce yoğun bir şekilde geliştirilen terör örgütleri ile ilişkisi olduğu yönünde oluşan haber içeriklerine yer verilmemiştir. Bu dönemde sadece "Rahip Brunson ve Papaz Brunson" gibi bir haber içerik üretimi geliştirilmiş, son yayınlanan haberle beraber ise Brunson'un masum ve suçsuz olduğu kabul edilmiştir.

Haber Girişleri: Andrew Brunson'un tutuklanıp serbest bırakıldığı dönem içerisinde Brunson'la ilgili yapılan haberlerde 42 , serbest bırakıldığı yargı süreci ve sonrasında ise 4 haber girişi bulunmaktadır. Bu haberlerin giriş metinleri aşağıda belirtilmektedir:

1. İzmir'de Protestan cemaatine ait kilisenin papazı Andrew Craig Brunson, FETÖ soruşturması kapsamında tutuklandı

2. FETÖ soruşturmasındaki bir gizli tanığın ifadeleri, oturma izni isteği yenilenmediği için sınır dışı edilmek üzere Göç İdaresi Müdürlüğü'nde bekletilirken FETÖ'den tutuklanan İzmir'deki Protestan cemaatine ait Diriliş Kilisesi Pastörü Andrew Craig Brunson'un gizemli ilişkilerini ortaya çıkardı

3. FETÖ operasyonu kapsamında tutuklanan Amerikalı rahip Brunson'ın, Suriye'den gelen PYD'li teröristleri kutsadığı ve kilisede Kürtçe ayin düzenlediği ortaya çıtı.

4. FETÖ soruşturması kapsamında tutuklanan İzmir Diriliş Kilisesi Rahibi Andrew Craig Brunson hakkında İzmir Cumhuriyet

5. FETÖ ile irtibatı belirlenen papaz Andrew Craig Brunson, "devletin gizli kalması gereken bilgilerini siyasi veya askeri casusluk amaciyla temin etme, Türkiye Büyük Millet Meclisini ortadan kaldırmaya teşebbüs etmek, Türkiye Cumhuriyeti hükümetini ortadan kaldırmaya teşebbüs etmek, Anayasal düzeni değiştirmeye teşebbüs " suçlamaları ile tekrar tutuklandı.

6. İzmir'de FETÖ üyesi olduğu gerekçesiyle tutuklu bulunan ABD'li din adamı Andrew Craig Brunson, darbe teşebbüsü ve askeri casusluk suçlarından da tutuklandı

7. FETÖ soruşturması kapsamında tutuklanan ve Cumhurbaşkanı Recep Tayyip Erdoğan'ın da gündeme getirdiği İzmir Diriliş Kilisesi Rahibi Andrew Craig Brunson hakkında İzmir Cumhuriyet Başsavcılığı'nın yürüttüğü soruşturmanın detayları belli oldu.

8. Türkiye ABD arasındaki krizde yeni bir gelişme yaşandı. FETÖ ile irtibatlarından dolayı tutuklanan ABD'li papazın şok ses kaydı ortaya çıktı.

9. 15 Temmuz darbe girişimi sonrası FETÖ'den tutuklanan Alsancak Diriliş Kilisesi Papazı Andrew Craig Brunson'la ilgili çarpıcı bir bilgiye ulaşıldı

10. İzmir'de terör örgütleri FETÖ ve PKK adına suç işlediği iddiasıyla tutuklu bulunan ABD'li din adamı Brunson hakkında 35 yıla kadar hapis cezası istemiyle hazırlanan iddianame mahkemeye sunuldu

11. ABD Başkanı Donald Trump'ın, Cumhurbaşkanı Recep Tayyip Erdoğan'la görüşmesi sırasında serbest bırakılmasını istediği rahip Brunson’a İttifak yasası müebbet istendi 
12. ABD'li din adamı Brunson hakkında hazırlanan iddianamede, sanı ğın ABD'li bir askere gönderdiği 15 Temmuz darbe girişiminin başarısız olmasından üzüntü duyduğuna ilişkin mesaj içerikleri yer aldı.

13. İzmir Cumhuriyet Başsavcılığı'nca terör örgütleri FETÖ ve PKK adına suç işlediği iddiasıyla tutuklu bulunan ABD'li din adamı Andrew Craig Brunson hakkında hazırlanan iddianame İzmir 2. Ağır Ceza Mahkemesi'nce kabul edildi.

14. İzmir'de terör örgütleri FETÖ ve PKK adına suç işlediği iddiasıyla tutuklu bulunan ABD'li din adamı Brunson hakkında 35 yıla kadar hapis cezası istemiyle hazırlanan iddianame mahkemece kabul edildi.

15. Trump'ın papazının darbe günü ABD'li askere gönderdiği mesajlar iddianamede yer aldı: İsa'ya dönmek için gerekli koşullar oluştu. Biz kazanacağız...

16. Son Dakika Haberi: İzmir'de terör örgütleri FETÖ ve PKK adına suç işlediği iddiasıyla tutuklu bulunan ABD'li din adamı Andrew Craig Brunson hakkında hazırlanan iddianamede, FETÖ ile PKK arasındaki bazı benzer öğeler ile Brunson'un iki örgütle nasıl planlı ve koordineli bir şekilde çalıştı̆̆ına ilişkin değerlendirmeler de yer aldı.

17. Amerikalı rahip Andrew Craig Brunson'a yönelik iddianamede Gizli Tanık Dua'nın polise ve savcılığa teslim ettiği dijital materyallerle ilgili detaylar da yer aldı

18. Son dakika haberi... FETÖ'cü papaz Andrew Craig Brunson hakkında hazırlanan iddianameden çok çarpıcı detaylar

19. İzmir'de, terör örgütleri FETÖ ve PKK adına suç işlediği iddiasıyla tutuklu bulunan ABD uyruklu din adamı Andrew Craig Brunson'un hakim karşısına çıkacağı tarih 16 Nisan olarak belirlendi

20. Diriliş Kilisesi papazı Andrew Brunson, PKK militanı gibi yetiştirdiği manevi oğlu Mehmet Ö, İzmir'deki Kürt kökenli vatandaşları Hristiyanlaştırmak için akıl almaz faaliyetler yürüttü.

21. FETÖ bağlantısı nedeniyle tutuklu olan ABD'li Papaz Brunson'un, daha önce tanımadığını söylediği FETÖ Ege bölge imamıla 293 kez aynı yerde bulunduğu ortaya çıktı

22. ABD Başkanı Donald Trump'ın, Cumhurbaşkanı Recep Tayyip Erdoğan'la görüşmesi sırasında serbest bırakılmasını talep etmesi ile ismi gündeme gelen, terör örgütleri FETÖ ve PKKadına suç işlediği iddiasıyla tutuklu bulunan ABD'li rahip Andrew Craig Brunson hakkında İzmir 2'nci Ağır Ceza Mahkemesi'nde açılan davaya başlandı

23. İzmir'de, terör örgütleri FETÖ ile PKK adına suç işlediği ve casusluk iddiasıyla 35 yll hapis cezası istenen ABD'li din adamı Andrew Craig Brunson'un yargılanmasına devam ediliyor

24. İzmir 2. Ağır Ceza Mahkemesi'nde terör örgütleri FETÖ ile PKK adına suç işlediği ve casusluk iddiasıyla 35 yıl hapsi istenen ABD'li din adamı Andrew Craig Brunson'ın yargılanmasına başlandı

25. İzmir'de FETÖ ile PKK adına suç işlediği ve casusluk yaptığı iddiasıyla hakkında 35 yıl hapis cezası istemiyle dava açılan ABDuyruklu din adamı Brunson'un tutukluluk halinin devamına karar verildi.

26. FETÖ ve PKK adına suç işlediği iddiasıyla tutuklu bulunan ve 35 yılla yargılanan ABD'li papaz Brunson adalet önünde hesap verdi.

27. ... Donald Trump'ın 'Papaz Brunson Türkiye'de zulme uğruyor' ifadelerinin ardından $\mathrm{ABD}$ 'den yeni bir açıklama geldi 
28. ... Donald Trump'ın iadesini istediği ABD'li Andrew Brunson'un ikinci duruşması başladı

29. İzmir'de terör örgütleri FETÖ ile PKK adına suç işlediği ve casusluk iddiasıyla hakkında 35 yıl hapis cezası istemiyle dava açılan ABD uyruklu din adamı Andrew Craig Brunson'in yargilanmasına devam edildi.

30. Terör örgütleri FETÖ ve PKK adına suç işlediği iddiasıyla tutuklu bulunan ve hakkında 35 yıl hapis cezası istemiyle dava açılan ABDuyruklu papaz Andrew Craig Brunson'un yargılandığı davada tanık ifadeleri dikkat çekti

31. İzmir'de, terör örgütleri FETÖ ve PKK adına suç işlediği ve casusluk iddiasıyla 35 yıla kadar hapis cezası istemiyle tutuklu yargılanan ABD'li rahip Andrew Craig Brunson, dün ikinci kez hakim karşısına çıktı.

32. FETÖ elebaşı Fetullah Gülen'le bağlantılı olduğu gerekçesiyle İzmir'de yargılanmasına devam edilen Rahip Andrew Brunson'un davasını takip eden New York Hristiyan Kilisesi rahiplerinden William Devlin'in The Christian Post'un internet sayfasında yayımlanan makalesinde, kamuoyuna Brunson ile Fetullah Gülen'in takas edilmesi önerisinde bulunuldu.

33. Terör örgütleri adına suç işlediği ve casusluk iddiasıyla 35 yıla kadar hapsi istenen tutuklu sanık ABD uyruklu din adamı Andrew Craig Brunson'ın bağlantısı olduğu öne sürülen bazı isimlerin, FETÖ'nün sözde üst düzey yöneticilerinden olması dikkati çekiyor.

34. FETÖ ve PKK adına suç işlediği ve casusluk yaptığı iddiasıyla yargılanan ABD'li rahip Andrew Craig Brunson'un tutukluluğu ev hapsine çevrildi

35. İzmir'de, terör örgütleri FETÖ ve PKK adına suç işleyip casusluk yaptığı iddiasıyla 35 yıl hapis cezası istenen ABD'li rahip Andrew Craig Brunson'un tutukluluğu ev hapsine çevrildi

36. Akıncı Üssü Davası'nın dosyasına giren itirafçı sivil imam Gökhan Erbağ'ın ifadeleri, FETÖ'nün Rahip Andrew Craig Brunson'un bağlı olduğu Evangelist tarikatının içine sızarak karar alma mekanizmalarını nasıl etkilemeye çalışıı̆ıııı ortaya koydu

37. İzmir 2. Ağır Ceza Mahkemesi, FETÖ ve PKK adına suç işlediği ve casusluk yaptığı iddiasıyla tutukluluğu "sağlık sorunları" gerekçe gösterilerek ev hapsine çevrilen ABD uyruklu din adamı Andrew Craig Brunson'ın ev hapsi ile yurt dışı çıkış yasağının kaldırılması için yapılan itirazı yeniden reddetti.

38. ABD ile Türkiye arasında krize neden olan rahip Brunson'ın PKK'nın şiddet eylemlerine başladığı Kobani olayları sırasında Suruç’ta olduğu ortaya çıktı

39. ABD ile Türkiye arasinda krize neden olan papaz Andrew Brunson'un, 20 Temmuz 2015'te 34 kişinin ölümüne, 70 kişinin yaralandığı canlı bomba saldırısı sırasında Şanlıurfa Suruç'ta olduğu ortaya çıktı

40. Hakkında casusluk iddiasıla 35 yıla kadar hapsi istenen ABD'li Rahip Andrew Craig Brunson'un 12 Ekim'de görülecek duruşması öncesi yeni gizli tanık ifadeleri ortaya çıktı.

41. ABD'nin Ankara Büyükelçiliği Maslahatgüzarı Jeffrey Hovenier, casusluk yaptığı iddiasıyla hakkında 35 yıl hapis cezası istenen, tutukluluğu ev hapsine çevrilen ABD'li din adamı Andrew Craig Brunson'ı, İzmir'deki evinde ziyaret etti.

42. Mahkeme heyeti Brunson'a son sözlerini sorarken, heyecandan sesi titreyen ABD'li rahip, "Masum bir adamım. İsa'yı seviyorum, Türkiye'yi seviyorum. Beraatımı talep ediyorum" dedi 
Sonuç olarak Andrew Brunson'un tutuklanıp serbest bırakıldığı döneme kadar yayınlanan haberlerin giriş cümleleri incelediğinde; Brunson'un Fethullahçı ve PKK terör örgütleri ile olan ilişkisi, hakkındaki casusluk ve terör faaliyetleri gibi iddialar sübjektif ifadelerle haber içeriğinin merkezini oluşturmaktadır. 2 numaralı "FETÖ'den tutuklanan İzmir'deki Protestan cemaatine ait Diriliş Kilisesi Pastörü Andrew Craig Brunson'un gizemli ilişkilerini ortaya çıkardı" haber girişinde "gizemli ilişki" şeklinde bir ifade kullanılmıştır. Gizem aleni olmayan, bir şeylerin gizlenmesi gerektiğini ifade eden anlamlarına gelmektedir. Dolayısıyla bu haberde Brunson'un FETÖ ile ilişkinin gizemli olduğu ifadesi söyleme öznellik katmıştır. Benzer şekilde 8 numaralı "Türkiye ABD arasındaki krizde yeni bir gelişme yaşandı. FETÖ ile irtibatlarından dolayı tutuklanan ABD'li papazın şok ses kaydı ortaya çıktı" haber girişinde ses kaydının "şok" sıfatıyla söylenmesi, 9 numaralı "15 Temmuz darbe girişimi sonrası FETÖ’den tutuklanan Alsancak Diriliş Kilisesi Papazı Andrew Craig Brunson'la ilgili çarpıcı bir bilgiye ulaşıldı" haber girişindeki "çarpıcı" ifadesi, 18 numaralı "Son dakika haberi... FETÖ'cü papaz Andrew Craig Brunson hakkında hazırlanan iddianameden çok çarpıcı detaylar" haber girişindeki "çarpıcı" ifadesi, 30 numaralı "Terör örgütleri FETÖ ve PKK adına suç işlediği iddiasıyla tutuklu bulunan ve hakkında 35 yıl hapis cezası istemiyle dava açılan ABD uyruklu papaz Andrew Craig Brunson'un yargılandığı davada tanık ifadeleri dikkat çekti" haber girişlerindeki tanık ifadelerinin "dikkat çekti" şeklinde söylenmesi ve 33 numaralı "Terör örgütleri adına suç işlediği ve casusluk iddiasıyla 35 yıla kadar hapsi istenen tutuklu sanık ABD uyruklu din adamı Andrew Craig Brunson'ın bağlantısı olduğu öne sürülen bazı isimlerin, FETÖ'nün sözde üst düzey yöneticilerinden olması dikkati çekiyor" haber girişindeki "dikkati çekiyor" ifadesi haber söylemine bir yanlılık katmaktadır. Diğer bir yandan haber içeriklerinin FETÖ ile ilişkilendirilerek bahsi geçen ifadelerle birlikte sunulması gazetenin suçlayıcı bir haber içeriği geliştirdiğini göstermektedir. Bunlara ek olarak 20 numaralı "Diriliş Kilisesi papazı Andrew Brunson, PKK militanı gibi yetiştirdiği manevi oğlu Mehmet Ö, İzmir'deki Kürt kökenli vatandaşları Hristiyanlaştırmak için akıl almaz faaliyetler yürüttü" haber girişindeki "PKK militanı gibi" ve "akıl almaz faaliyetler" ifadeleri incelendiğinde, haber girişlerinde tamamen yanlı, itibarsızlaştırmaya yönelik, suçlayıcı ve kışkırtıcı bir şekilde haber içeriklerinin oluşturulduğu görülmektedir. Yine aynı minvalde yapılan haberde olayın ne zaman ve nasıl gerçekleştiğine dair herhangi bir bilgi haber sunuş biçimine yansımamaktadır.

Andrew Brunson'un serbest birakıldığı yarg1 süreci ve sonrası dönemde Brunson'la ilgili Sabah internet gazetesinde yapılan haberlerin giriş cümleleri şunlardır:

43. Rahip Brunson sabah saatlerinde yoğun güvenlik önlemleri ile birlikte davanın 4. duruşmasının görüleceği Aliağa Ceza İnfaz Kurumları Kampüsü'ne saat 06.45 sıralarında getirildi. Peki Rahip Brunson serbest bırakıldı mı? İşte mahkemenin kararı!

44. Son dakika... Türkiye ile ABD arasında gerilime neden olan ABD'li papaz Andrew Craig Brunson, dördüncü kez hakim karşısına çıkmaya hazırlanırken, Brunson, davanın görüleceği Aliağa Ceza İnfaz Kurumları Kampüsü’ne getirildi

45. ABD Başkanı Donald Trump, dün tahliye edilen Brunson'u Beyaz Saray'da ağırladı. Trump, “Cumhurbaşkanı Erdoğan'a bir kez daha çok teşekkür ediyorum.

46. FETÖ'nün mağdurlarından emekli askeri hâkim Ahmet Zeki Üçok, mahkemenin Rahip Andrew Brunson davasında verdiği kararın hukuka uygun olduğunu söyledi.

Andrew Brunson'un serbest kaldığı son yargı kararı ve sonraki süreçte Sabah internet gazetesinde yayınlanan haberlerin girişleri irdelendiğinde; 43 ve 44 numaralı haber girişlerinde genel olarak süreç tarafsız bir söylemle verilmiştir. Ancak 46 numaralı "FETÖ'nün mağdurlarından emekli askeri hâkim Ahmet Zeki Üçok, mahkemenin Rahip Andrew Brunson davasında verdiği kararın hukuka uygun olduğunu söyledi" haber girişinde "FETÖ mağduru" ve "emekli hâkim" sıfatı verdiği birinin açıklamalarıyla Brunson'un serbest bırakılmasının hukuka uygun olduğu ifade edilmektedir. 
Gazetenin burada Brunson’un bir nevi FETÖ mağduru olduğunu ve serbest bırakılmasılla adaletin sağlandığı şeklinde dolaylı bir söylem gerçekleştirmeye çalıştığ1 görülmektedir.

Bütüncül açıdan Sabah internet gazetesi haber girişleri incelendiğinde, Brunson'un tutuklanıp serbest bırakıldığı dönem ile serbest bırakıldıktan sonraki süreçte geliştirilen haber içerik ve sunuş biçimlerinin farklılık gösterdiği dikkat çekmektedir. Brunson'un serbest bırakıldığı döneme kadar FETÖ, PKK ile ilişkili olduğu üzerinden haber içerikleri oluşturularak bazı haber girişlerinde tamamen suçlayıcı, itibarsızlaştırıcı bir dil kullanılmıştır. Serbest bırakıldıktan sonra ki süreçte ise özellikle FETÖ mağduru emekli bir Hâkim'in haber içeriğine konu edilmesi birinci dönemdeki haber içerik üretim ve sunuş biçiminin tam tersine döndüğünü göstermektedir.

Fotoğraflar: Makro yapı içinde yer alan fotoğraflar haber anlatısındaki temayı oluşturan tematik yapının bir unsuru olarak ele alınmaktadır. İncelenen haberlerde kullanılan fotoğraflara bakıldığında haber anlatısında oluşturulmaya çalışılan temayı destekler nitelikte görsel malzemelerin kullanıldığı görülmüştür.

Brunson'un gözaltına alınmasıyla birlikte yapılan ilk haberlerde eşi ile beraber olduğu fotoğraflara yer verilmiş ancak ilerleyen dönemlerde PKK terör örgütü militanları ve FETÖ lideri Fethullah Gülen'in fotoğrafı ile aynı karede yer aldığı şekliyle haberler sunulmaya başlanmıştır. Yargılanma süreci boyunca ise mahkemeye götürülürken ve tutuklanmış haldeki fotoğraflarının yayınlandığı gözlemlenmiştir. Aynı zamanda haberleștirilen fotoğraflarda kalın puntolu harflerle suçlayıcı kelimelerin ön plana çıkarıldığı görülmüştür.

Özetle Brunson'un yakalanıp serbest bırakıldığı döneme kadar yayınlanan haberlerde suçlayıcı bir dil kullanılarak yargılanma süreciyle ile ilgili fotoğrafların yer aldığı aynı zamanda haberlerin içerik üretimleri ve sunuş biçimlerinin terör örgütleriyle ilişkilendirildiği şekliyle servis edildiği dikkat çekmiştir. Brunson'un yargılama süreci sonunda serbest bırakılmasını içeren sonraki dönemde ise Amerika Birleşik Devletleri başkanı Trump ile beyaz sarayda görüşmesi ve eşi ile birlikte tebessüm ederken yayınlanmış fotoğrafları yer almıştır. Dolayısıyla Brunson hakkında serbest bırakıldıktan sonra yayınlanan haberlerde herhangi bir suçlayıcı dil kullanılmamış ve yargılanma süreciyle ile ilişkilendirilen bir görüntüye yer verilmemiştir. Bu durum Brunson'un tutukluluk sürecindeki yayınlanan fotoğraflarıyla kıyaslandığında haber içerik ve sunuş biçimlerinin her iki dönem açısından farklılaştığını görmemizi sağlamıştır.

\section{Şematik Yapı İncelemesi}

Ana Olayın Sunumu ve Sonuçlar: İncelenen gazetenin haber başlıkları ve girişlerinde Brunson'un tutuklanıp serbest bırakıldığ d dönemle tahliye edildiği yargılanma dönemi ve sonrasındaki süreç irdelendiğinde iki ana olay ortaya çıkmaktadır. İlk dönemde sunulan ana olay, Brunson'un terör örgütleri ve eylemleriyle ilişkisi, ikinci dönemde ise Brunson hakkında verilen tahliye kararıdır. Bu başlıklar ve giriş cümleleri temel olarak şu sonuçları ortaya çıkarmaktadır: Yargı Brunson'la ilgili herhangi bir karar vermeden, hakkında sadece iddialar söz konusuyken Sabah internet gazetesi Brunson'un FETÖ ve PKK ile ilişkili olduğu ve Türkiye'de meydana gelen bazı terör eylemlerinde parmağının bulunduğu hükmünü vermiştir. Daha sonraki süreçte ise mahkemenin tahliye kararı neticesinde FETÖ mağduru ve emekli askeri hakim diye nitelendirdiği kişinin görüşünü haberine yansıtarak kararın doğru olduğunu o kişinin ağzından dile getirmiştir. Bu iki sonuç bağlamında Sabah internet gazetesinin haber içerik üretim ve sunuş biçimleri açısından yansız ve nesnel davranmadığ gerçeği ortaya çıkmıştır.

Ardalan ve Bağlam Bilgisi: Haberlere bakıldığında yeterli ardalan ve bağlam bilgisinin bulunmadığı görülmektedir. Bu bağlamda Brunson, 15 Temmuz 2016 tarihinde Fethullahçı Terör Örgütü'nün (FETÖ) darbe girişimiyle başlayan dönem sonrası PKK ve Fethullahçı terör örgütleriyle ilişkisinin olduğu iddia edilerek haberlere konu olmuş kişidir. Daha öncesinde hakkında herhangi bir haber bulunmamaktadır. 
Haber Kaynakları ve Olay Taraflarının Değerlendirmeleri: İncelenen haberlerin kaynaklarını, çoğunlukla gazetenin başta kendi muhabirleri olmak üzere NTV (Nergis Televizyon), İHA (İhlas Haber Ajans1), DHA (Demirören Haber Ajans1), AA (Anadolu Ajansı) ve Yeni Asır gazeteleri oluşturmaktadır.

Sabah internet gazetesinin Andrew Brunson'un tutuklanıp tahliye olduğu yargı sürecine kadar ki haber içerik üretimlerinde taraflı bir dil kullanmayı tercih ettiği gözükmektedir. Bu süreçte gazeteye göre Andrew Brunson suçludur ve haberler bu dil kullanımı altında şekillenmektedir. Ancak yargı sürecinde savcılık iddiaları ve yargı kararları tırnak içerisinde verilerek doğrudan bir anlatıma başvurulmuştur. Bu söylemlere örnek verecek olursak:

FETÖ ve PKK adına suç işlediği ve casusluk yaptığı iddiasıyla tutukluluğu sağllk sorunları gerekçe gösterilerek ev hapsine çevrilen ABD'li papaz Andrew Craig Brunson'ın Whatsapp mesajları savcılığın iddianamesine girdi. Mesajlarda, İzmir'de görevli olan papazın PKK'nın şiddet olaylarını gerçekleştirdiği yerlerde olduğu açıkça görülüyor. İzmir Cumhuriyet Başsavcıllğı'nın iddianamesinde, Brunson'ın yurtdışı ve yurtiçinden numaralarla yaptığı bu mesajlaşmalarına yer verildi. İddianamede, Andrew Brunson'ın, mesajlarından HDP'nin çağrısıyla başlayan ve PKK'nın sokaklarda şiddet eylemlerine başladığı Kobani olayları sırasında Suruç'ta olduğuna dikkat çekiliyor.

Burada gazete kendi yorumunu katarak Brunson'un şiddet olaylarının gerçekleştiği yerlerde olduğunu iddia etmektedir.

İzmir Cumhuriyet Savcısı Berkant Karakaya tarafından hazırlanan ve İzmir 2. Ağır Ceza Mahkemesince kabul edilen iddianamede, hakkında "örgüte üye olmamakla birlikte örgüt adına suç işlediği" gerekçesiyle 15 , "devletin gizli kalması gereken bilgileri siyasal veya askeri casusluk amaciyla temin etmek" suçlamasıyla 20 yıla kadar olmak üzere toplam 35 y1l hapis cezası istenen Brunson'un, Türkiye genelinde misyonerlik görüntüsü altında casusluk ve örgütsel faaliyetler yürüttüğ̈̈, FETÖ ve PKK mensuplarıyla irtibatının bulunduğu, görüşmeler yaptığı, din adamlığını perde gibi kullanarak, ülkenin içişlerine müdahil olmaya çalıştı̆̆ belirtildi.

Salona giren mahkeme başkanı, Andrew Craig Brunson'a "Üzgünsün, ağlıyorsun. Sakinleşmen için müsaade edeceğiz." dedi. Brunson da "Psikolojim bozuldu. İlaç almaya başladım. Bir şey yemiyorum. Daha önce Buca'daki cezaevindeydim, duruşma için Şakran'a getirildim. Sorun burada değil kafamda. Eğer tahliye edilmeyeceksem Buca'daki cezaevinde kalmayı talep ediyorum." diye konuştu.

Bu haber içeriğinde görüldüğü gibi gazete yargı sürecindeki savcılık iddialarını, mahkemede yaşanan olay ve konuşmaları doğrudan aktarmıştır.

Andrew Brunson'un tahliye olduğu yargı süreci ve sonrasında Sabah internet gazetesinin suçlayıcı dil kullanımını terk ederek olayları tarafsız bir şekilde aktarmaya başladığı görülmektedir. Bu çerçevede yayınlanan haber içeriklerinde Brunson'un serbest kalma durumu tırnak içerisinde bir tanık tarafından doğrudan alıntı yapılarak servis edilmektedir.

Mahkemenin son dakika kararı ile ABD'li rahip Brunson serbest bırakıldı. (3 yıl 1 ay 15 gün hapis cezası aldı. Yattığı süre göz önünde bulundurularak serbest bırakıldı.

Mahkemenin iddianameye göre hareket ettiğini, hukuka uygun davrandığını belirten Üçok, buna rağmen linç edildiğini vurguladı. Üçok şunları söyledi: "A partisinin başkanı şöyle demiş, B partisinin başkanı böyle demiş. Bunlar mahkemeyi ilgilendiren şeyler değil ki. Biz mahkemelerimizi aşağılamaktan, bağımsız olmadığını söylemekten zevk alır bir hale geldik. Mahkeme elindeki delillerle bunun dışında bir karar verseydi bağımsız olmadığını söyleyebilirdiniz. Bu delillerle verdiği karar hukuka uygundur. Bu kadar baskıya rağmen elindeki dosyaya göre karar verdiği için mahkeme heyetini de kutlarım. Ben hukukçu olarak bundan başka hiçbir karar veremezdim. Sabih Kanadoğlu da başka bir karar veremezdi." 
$\mathrm{Bu}$ haberlerde, Sabah internet gazetesinin Andrew Brunson hakkındaki yarg1 süreci ve sonrasında meydana gelen olaylara yönelik tarafsız bir dil geliştirdiği ve doğrudan anlatıma yer verdiği görülmektedir. Ancak bu durum daha önceki haber içerik ve sunuş biçimleri dikkate alındığında gazetenin aslında tarafsız değil taraf değiştirdiğini göstermektedir. $\mathrm{Bu}$ bağlamda gazetenin Brunson'un tahliyesini destekleyici bir dil kullanımına geçiş yapması o dönemin hegemonik şartları gereği olduğu gerçeğini ortaya çıkartmaktadır.

\section{Mikro Yapı İncelemesi: Sentaktik Çözümleme, Bölgesel Uyum, Sözcük Seçimleri, Haberin Retoriği}

Sentaktik Çözümleme: Sentaktik çözümlemede, metinde yer alan cümlelerin yapısı, cümlenin nasıl kurulduğu ve öznenin konumlandırılma biçimi ön plana çıkmaktadır.

ABD'li din adamı Brunson hakkında hazırlanan iddianamede, sanığın ABD'li bir askere gönderdiği 15 Temmuz darbe girişiminin başarısız olmasından üzüntü duyduğuna ilişkin mesaj içerikleri yer aldı (Birinci dönem).

Diriliş Kilisesi papazı Andrew Brunson, PKK militanı gibi yetiştirdiği manevi oğlu Mehmet Ö, İzmir'deki Kürt kökenli vatandaşları Hristiyanlaştırmak için akıl almaz faaliyetler yürütttü (Birinci dönem).

Amerikalı rahip Andrew Craig Brunson'a yönelik iddianamede Gizli Tanık Dua'nın polise ve savcılığa teslim ettiği dijital materyallerle ilgili detaylar da yer aldı (Birinci dönem).

Terör örgütleri adına suç işlediği ve casusluk iddiasıyla 35 yıla kadar hapsi istenen tutuklu sanık ABD uyruklu din adamı Andrew Craig Brunson'ın bağlantısı olduğu öne sürülen bazı isimlerin, FETÖ'nün sözde üst düzey yöneticilerinden olması dikkati çekiyor (Birinci dönem).

Rahip Brunson sabah saatlerinde yoğun güvenlik önlemleri ile birlikte davanın 4. duruşmasının görüleceği Aliağa Ceza İnfaz Kurumları Kampüsü'ne saat 06.45 sıralarında getirildi. Peki Rahip Brunson serbest bırakıldı mı? İşte mahkemenin kararı! (İkinci dönem).

Son dakika... Türkiye ile ABD arasında gerilime neden olan ABD'li papaz Andrew Craig Brunson, dördüncü kez hakim karşısına çıkmaya hazırlanırken, Brunson, davanın görüleceği Aliağa Ceza İnfaz Kurumları Kampüsü’ne getirildi (İkinci dönem).

Bahsi geçen karşılaştırmanın öncesi ve sonrası yayınlanan örnek metinler incelendiğinde, olaylar etken yapıyla verilmiştir. Olayın ana öznesini Andrew Brunson oluşturmuş ve haber metinlerinde Andrew Brunson çoğunlukla etken özne olarak sunulmuştur. Cümle yapısı olarak ise çoğunlukla kurallı ve sıralı cümle tercih edilmiştir.

Bölgesel Uyum: Andrew Brunson'un tutuklanıp tahliye edildiği yarg1 sürecine kadarki haber metinleri incelendiğinde, daha çok nedensel ve işlevsel ilişkiye dayalı bir anlatımın ön plana çıktığ1 tespit edilmiştir. Haber metinlerinde bu ilişki açı bir şekilde görülmektedir:

"Örgüte üye olmamakla birlikte örgüt adına suç işlediği" gerekçesiyle 15 yıla kadar, "Devletin güvenliği bakımından niteliği itibarıyla gizli kalması gereken bilgileri siyasal ve askeri casusluk maksadıyla temin etmek" suçlamasından 20 yıla kadar hapis cezası talebiyle yargılanan Brunson, hakkındaki iddialara karşı savunmasını Türkçe yaptı.

İzmir'de, terör örgütleri FETÖ ve PKK adına suç işlediği, casusluk yaptığı iddiasıyla hakkında 35 yıl hapis cezası istenen ve "sağlık sorunları" dikkate alınarak cezası "ev hapsine" dönüştürülen ABD'li din adamı Andrew Craig Brunson cezaevinden çıktı.

Bahsi geçen örnek metinlerde Andrew Brunson hakkında talep edilen cezanın nedenleri ortaya konularak anlatılmıştır: 
Brunson'un Türk savaş uçağı pilotlarının başarısından bahseden bir Türk vatandaşına ise "Sizin pilotunuz yok ki. Onlar bizim oradaki hocanın (Örgüt elebaşı Fetullah Gülen kastedilerek) duasıyla uçan pilotlar. Onlar (FETÖ ile ilișkisi olan askerler kastedilerek) hocaya, hoca da bize bağlı." şeklindeki diyalogları da iddianamede yer aldı.

Diriliş Kilisesi papazı Andrew Brunson ve PKK militanı gibi yetiştirdiği manevi oğlu Mehmet Ö, İzmir'deki Kürt kökenli vatandaşları Hristiyanlaştırmak için akıl almaz faaliyetler yürüttü. İzmir'de ajanlık suçlamasıyla tutuklu bulunan ve 35 yıla kadar hapsi istenen ABD'li papaz Andrew Craig Brunson'un, Hristiyan olmak için ikna ettiği Kürt kökenli vatandaşları, yaklaşık iki aylık din eğitimlerinin ardından İzmir Körfezi'nde vaftiz ettiği ortaya çıktı.

Yukarıda ki metinler işlevsel ilişki açısından ele alındığında, ilkinde Andrew Brunson'ın bir konuşmasında geçen cümle içindeki "hoca" ve "pilotlar" kelimeleri parantez içinde. İkincisinde ise Brunson'un akıl almaz faaliyetleri bir sondaki cümlede açılanmıştır.

Andew Brunson mahkeme tarafından serbest bırakıldıktan sonraki süreçteki haber içeriğinde referansal ilişki kullanıldığı görüşmüştür:

"A partisinin başkanı şöyle demiş, B partisinin başkanı böyle demiş. Bunlar mahkemeyi ilgilendiren şeyler değil ki. Biz mahkemelerimizi aşağılamaktan, bağımsız olmadığını söylemekten zevk alır bir hale geldik. Mahkeme elindeki delillerle bunun dışında bir karar verseydi bağımsız olmadığını söyleyebilirdiniz. Bu delillerle verdiği karar hukuka uygundur. Bu kadar baskıya rağmen elindeki dosyaya göre karar verdiği için mahkeme heyetini de kutlarım. Ben hukukçu olarak bundan başka hiçbir karar veremezdim. Sabih Kanadoğlu da başka bir karar veremezdi."

Örnek metinde emekli askeri hakim Zeki Üçok'un ifadelerine yer verilmekte, bu ifadelerin ikinci cümlesinde yer alan "bağımsızlık" kavramıyla bir sonraki cümlede bulunan "elindeki deliller" ifadesi arasında bir bağın bulunduğu anlaşılmaktadır. Bu bağa göre ise bağımsız olmanın referansı elde bulunan delilleri işaret etmektedir.

Sözcük Seçimleri: Andrew Brunson'un tutuklanıp tahliye edildiği süreç içerisinde Sabah internet gazetesinde Brunson hakkında yayınlanan haber metinlerinin genelinde Brunson FETÖ, PKK ve PYD gibi terör örgütleriyle ilişkilendirilerek birçok haberde ABD'li ve FETÖ'cü sifatıyla anılmıştır. Bu dönemde az da olsa Rahip ve Papaz sıfatları da kullanılmıştır. Brunson'un serbest bırakılma süreci ve sonrasında ise bahsi geçen terör örgütlerinin isimlerine hiçbir şekilde yer verilmediği, kendisinden bahsedilirken sadece Papaz ve Rahip sıfatlarının kullanıldığı dikkat çekmiştir. Bu iki dönem karşılaştırıldığında sözcük seçimlerinde önemli bir farkın olduğu tespit edilmiştir.

Haberlerin Retoriği: Andrew Brunson'un tutuklu bulunduğu süreç ve sonrası dönem Brunson'la ilgili Sabah internet gazetesi haberleri haber retoriği açısından fotoğraf, sayısal veri ve alıntı olmak üzere üç unsur çerçevesinde ele alınmıştır.

Her iki dönemde de Brunson'un sıradan ve eşiyle beraber olduğu fotoğraflara yer verilmiştir. Ancak ilk dönemde Brunson'un bulunduğu fotoğraf karelerine photoshop kullanılarak PKK terör örgütü militanlarının, FETÖ lideri Fethullah Gülen'in ve Amerika Birleşik Devletleri başkanı Donald Trump'ın fotoğrafı eklenmiştir. Bu durum Brunson'un terör örgütleriyle ilişkisinin olduğunu desteklemeye yönelik gerçekleştirilmiştir. Aynı zamanda Trump'ın fotoğraflarda yer alması ise onun süreç içerisine dahil olduğu izlenimini yaratmayı amaçlamıştır.

İnandırıcılığı artırmak amacıyla özellikle birinci dönem haber metinlerinde sayısal verilere ve alıntılara başvurulduğu tespit edilmiştir:

Brunson 6 yıl öncesine ait ses kaydında gence, 15 Temmuz 2016'da yapılacak darbe girişimine atıfta bulunurcasına, "2016 yılında yaz aylarında büyük bir deprem 
olacak. Bunları önemli ve her an bulabileceğin bir yere sakla. O depremden sonra İstanbul ABD Konsolosluğuna benim yanıma gel" diyor.

Terör örgütleri FETÖ ve PKK adına suç işlediği ve casusluk yaptığı iddiasıyla 35 y1la kadar hapis cezası istenilen ABD'li din adamı Andrew Craig Brunson'un, görüşmediğini öne sürdüğü FETÖ'nün sözde Ege Bölge imamı firari sanık Bekir Baz ile birbirlerine çok yakın yerde $293 \mathrm{kez}$ GSM sinyali tespit edildi.

Brunson'ın, görüşmediğini öne sürdüğü FETÖ'nün sözde Ege Bölge imamı firari sanık Bekir Baz ile birbirlerine çok yakın yerde 293 kez GSM sinyali tespit edilmişti.

Bahsi geçen metinlerin ilkinde, Brunson'un ses kaydında geçtiği iddia edilen bir alıntıya yer verilmiş, diğer metinlerde ise FETÖ terör örgütüne mensup birisiyle 293 kez GSM sinyalinden bahsedilerek sayısal bir veri kullanılmıştır. Fotoğraflarda olduğu gibi bu örnek metinlerde de Brunson'un terör örgütleri ve teröristlerle ilişkisi olduğu okuyucuya inandırılmaya çalışılmıştır.

\section{Sonuç}

Medyanın yansız, tarafsız, dengeli ve nesnel haber üretim sorunsalı geçmişte olduğu gibi günümüzde de tartışılagelen bir konudur. Özellikle liberalleşmenin bir sonucu olarak medyanın endüstrileşme süreci sonucunda geçmişte var olan siyasi amaçlar için içerik üretimi aynı zamanda ekonomik kaygılar içinde var olmaya başlamıştır. Ekonomik kaygılardan dolayı olay ve olgulara tarafsız yaklaşım yerini çıkar odaklı bir yaklaşıma bırakmıştır. Bu bağlamda medya özellikle haber üretim içerik ve sunuş biçimlerini gücü elinde bulunduran paydaşların istediği biçimde şekillendirebilmektedir. Bu paydaşlardan biri de siyasi iktidarlardır.

Günümüzde siyasi iktidarlar, medyada etkin rol oynayarak haber içerik üretimlerine çıkarlarına uygun olacak biçimde müdahale edebilmektedirler. Bu durum medyanın tarafsızlığına ve nesnelliğine gölge düşürmekte, egemen söylemin tekrarını sağlayan bir araç olmasına neden olmaktadır. Kapitalist dünya düzeninde olduğu gibi ülkemizde de bu işleyişin devam ettiği görülmektedir. Dolayısıyla bu çalışmada, Türk basınında da hegemonik bir söylemin var olduğu varsayımından yola çıkılarak bu söylemi ortaya koyabilmek için dönemin internet gazete tiraj1 sıralamasında ilk üçte, nispeten iktidara yakın olması konumunda ise birinci sırada yer alan Sabah internet gazetesi haberleri içerik üretim ve sunuş biçimleri açısından Türkiye için bir kriz niteliği taşıyan Andrew Brunson olayı özelinde mercek altına alınmıştır. Siyasi iktidarın Brunson’un tutuklanma, yargılanma ve serbest bırakılma dönemlerinde geliştirdiği söylemler ile Sabah internet gazetesinin bu dönemlerde ürettiği haber içerik ve sunuş biçimleri karşılaştırmalı bir analize tabi tutulmuştur.

Tutarlı ve birbirini tamamlar nitelikte bulgular elde etmek amacıyla gerçekleştirilen veri analizlerinde haber başlıkları, haber girişleri ve fotoğraflar açısından karşılaştırılan iki dönem arasında önemli ölçüde farklılaşma olduğu tespit edilmiştir. Andrew Brunson'un tutuklanıp yargılandığı süreçte iktidarın söylemlerine paralel olarak gazete yayınlanan haber başlıklarında, haber girişlerinde ve fotoğraflarda Brunson'un terör örgütleri ve terör eylemleriyle ilişkisi başta olmak üzere birçok kirli amaca hizmet ettiğinden bahsedildiği görülmüştür. Siyasi iktidarın hem ilk dönemde hem de ikinci dönemde geliştirdiği farklı söylemler Sabah internet gazetesinin haber içerik üretim ve sunuş biçimine aynı paralelde yansımıştır. Bu çerçevede ilk dönemde sunulan ana olay Brunson'un terör örgütleri ve eylemleriyle ilişkisi, ikinci dönemde ise Brunson hakkında verilen tahliye kararı ve bu kararın hukuka uygunluğu şeklinde vuku bulmuştur. İlk dönemde siyasi iktidarın olumsuz söylemleri paralelinde haber içeriklerinde ana olay Brunson'un terör örgütleri ve eylemleriyle ilişkisi üzerinden, ikinci dönemde ise siyasi iktidarın yumuşayan söylemleri minvalinde haber içerikleri Brunson hakkında verilen tahliye kararı ve bu kararın hukuka uygunluğu üzerinden seyretmiştir. Birinci dönemde Sabah internet gazetesinde dikkat çeken husus Brunson hakkında terör örgütleri ve terör eylemleriyle ilişkili delillerden haber içeriklerinde sıklıkla bahsedilmiş olmasıdır. Yargı kararı sonucu Brunson’un serbest bırakılmasıyla ortaya çıkan ikinci dönemde ise göze çarpan 
unsur, kararın hukuka uygun olduğu yönünde haber içerik üretiminin oluşturulmasıdır. İlk dönemde siyasi iktidarın söylemleri paralelinde yayınladığı haberlerde birçok delile yer veren gazete, ikinci dönemde yine siyasi iktidarın söylemi paralelinde hareket ederek kararın hukuka uygun olduğu yönünde haber içeriklerini düzenlemiştir. Yukarıda bahsi geçen süreç içerisinde sözcük seçimleri ve haber retoriğinde de gazetenin siyasi iktidarla aynı minvalde hareket ettiği gözlemlenmiştir. İlk dönemdeki sözcük seçimlerinde FETÖ'cü sıfatıyla birçok haber içeriği oluşturulmuş, Brunson yarg1 tarafından serbest bırakıldıktan sonra oluşan ikinci dönemde ise sadece rahip ve papaz sıfatlarına haber içeriklerinde yer verilmiştir. Benzer şekilde Brunson'la ilgili haberlein fotoğrafları tutukluluk sürecinde FETÖ lideri Fethullah Gülen ve PKK terör örgütü militanlarıyla aynı karede servis edilmiş ancak Brunson serbest bırakıldıktan sonra böyle bir kareye rastlanmamıştır.

Tüm bu süreç ışığında siyasi iktidarın söylemlerinin farklılaşması ve bu noktada gazete haber içerik ve sunuş biçimlerine aynen yansıması mevcut hegemonyaya uygun yapıda hareket edildiğini gözler önüne sermiştir. Andrew Brunson olayı özelinde bu farklılaşma basında hegemonik bir söylemin olduğunu destekler nitelikte sonuçlara ulaşmamızı sağlamıştır.

\section{Kaynakça}

Bâlan, S. (2010). M. Foucault's view on power relations. Bucherest Academy of Economic Studies, 2 ,

http://cogito.ucdc.ro/sitev/nr_2v2/M.\%20FOUCAULT'S\%20VIEW\%20ON\%20POWER\% 20RELATIONS.pdf

Baltacı, A. (2018). Nitel araştırmalarda örnekleme yöntemleri ve örnek hacmi sorunsalı üzerine kavramsal bir inceleme. Bitlis Eren Üniversitesi Sosyal Bilimler Enstitüsü Dergisi, 7(1), 231-274. https://avys.omu.edu.tr/storage/app/public/ngenc/58787/11.\%20hafta.pdf

Bbc.com (2018). “Erdoğan'dan Trump'ın Brunson teşekkürüne yanıt: Sayın başkan, Türk yargısı kararını bağımsız bir şekilde verdi.” https://www.bbc.com/turkce/haberler-dunya-45849057 (Erişim Tarihi: 22.11.2018).

Çamdereli, M. (2013). Medyanın dilsel etik sorumluluğu, Kocaeli Üniversitesi İletişim fakültesi Araştırma Dergisi, 9, 173-182. http://baskanlikreferandumu.siyasaliletisim.org/wpcontent/uploads/2009/08/medyanindilseletiksorumlulugu.pdf

Çelik, H. \& Ekşi, H. (2008). Söylem analizi. Marmara Üniversitesi Atatürk Eğitim Fakültesi Eğitim Bilimleri Dergisi, 27, 99-117, https://dergipark.org.tr/en/pub/maruaebd/issue/365/2517

Çoban, S. (2011). Hegemonya aracı ve ideolojik aygıt olarak medya [Yayınlanmıs doktora tezi]. Marmara Üniversitesi Sosyal Bilimler Enstitüsü.

Çoban, S. (2012). Gramsci, hegemonya ve kapitalizm. International Interdisciplinary Social Inquiry Conference. Bursa.

Çoban, S. (2013). İktidar medyası. Medya ve İktidar-Hegemonya, Statüko, Direniş. (Eds: E. Arslan, S. Arslan). Evrensel Basim.

Çetin, H. (2003). Siyasetin evrensel sorunu: İktidarın meşruiyeti-meşruiyetin iktidarı. Ankara Üniversitesi Siyasal Bilgiler Fakültesi Dergisi, 58 (3), 61-88. https://acikerisim.cumhuriyet.edu.tr/xmlui/handle/20.500.12418/1413

Dalgalıdere, S. (2011). Eleştirel ekonomi politiğe bakış. Dincle Üniversitesi İktisadi ve İdari Bilimler Fakültesi Dergisi, 1 (2), 70-85. https://dergipark.org.tr/en/download/article-file/370667

Devran, Y. (2010). Haber-söylem-ideoloji. Başlık Yayın Grubu.

Erdoğan, İ. (2014). Medya teori ve araştırmaları. Erk Yayınlanı. 
Gazetetirajlari.com (2018). “Gazete tirajları.” http://gazetetirajlari.com/HaftalikTirajlar.aspx (23.11.2018).

Güneş, C. D. (2013). Michel Faucault'da söylem ve iktidar. Uludağ Üniversitesi Fen-Edebiyat Fakültesi Felsefe Dergisi, 21, 55-69.

Güngör, N. (2018). Illetişim kuramlar yaklaşımlar. Siyasal Kitapevi.

Haberler.com (2018). Ak Parti'den dikkat çeken rahip Brunson açıklaması Yargının bağımsız olduğunu gördüler. https://www.haberler.com/ak-parti-den-dikkat-ceken-rahip-brunson11327048-haberi/ (22.11.2018).

Haberturk.com (2018). "Son dakika... Cumhurbaşkanı Erdoğan'dan rahip Brunson açıklaması." https://www.haberturk.com/son-dakika-cumhurbaskani-erdogan-dan-rahip-brunsonaciklamasi-2156707 (22.11.2018).

Hall, S. (1992). The West and the Rest: Discourse and power. Polity Press In Association With the Open University. Sage: 185-225.

Herman, E. \& Chomsky, N. (2012). Rızanın İmalatı-kitle medyasının ekonomi politiği.(Çev.Ender Abadoğlu). Bgst Yayınları.

Karaduman, S. (2017). Eleştirel söylem çözümlemesinin eleştirel haber araştırmalarına katkısı ve sunduğu perspektif. Maltepe Üniversitesi İletişim Fakültesi Dergisi, İstanbul, 4(2), 31-46. http://openaccess.maltepe.edu.tr/xmlui/handle/20.500.12415/2543\#sthash.yyIzYm7s.dpbs

Marshall, G. (1999). Sosyoloji sözlüğ̈̈̈. (Çev. Osman Akınhay ve Derya Kömürcü) Bilim ve Sanat Yayınları.

Mora, N. (2008). Medya, toplum ve haber kaynağı olarak sembolik seçkinler. Uluslarası İnsan Bilimleri Dergisi, 5(1), 1-25. https://pdfs.semanticscholar.org/ee87/b88977bf41375dc9cddac0534464a1e8a38b.pdf

Portelli, H. (1982). Gramsci ve tarihsel blok. (Çev. Kenan Someer) Savaş Yayımları.

Purvis, T. ve Hunt, A. (2014). Söylem ideoloji, söylem ideoloji, söylem ideoloji... (Çev. Simten Coşar) Moment Dergisi. 1. 9-36, 10.17572/mj2014.1.936. http://momentjournal.org/index.php/momentdergi/article/view/38

Russel, B. (1976). İktidar. (Çev. Mete Ergin), Cem Yayınevi.

Sabah.com.tr (2018). "Oyununuzu gördük meydan okuyoruz." https://www.sabah.com.tr/gundem/2018/08/13/oyununuzu-gorduk-meydan-okuyoruz\# (18.11.2018).

Solak, Ö. (2011). Küçük ağa romanının eleştirel söylem analizi. Akademik Bakış Dergisi. 26: 1-14. https://www.acarindex.com/dosyalar/makale/acarindex-1423868117.pdf

Sözeri, C. (2015). Türkiye'de medya-iktidar ilişkileri / sorunlar ve öneriler. İstanbul Toplum Siyaset ve Ekonomi Araştırmaları Enstitüsü. http://platform24.org/Content/Uploads/Editor/T\%C3\%BCrkiye\%E2\%80\%99de\%20Medya -\%C4\%B0ktidar\%20\%C4\%B0li\%C5\%9Fkileri-BASKI.pdf

Şengül, T. (2015). “İktidar.” Siyaset Bilimi Kavramlar, İdeolojiler, Disiplinler Arası İlişkiler (Eds. Atılgan, G. ve Aytekin, E. A.). Yazın Basın Yayın Matbaacılık, Stage 41-54.

Şimşek, S. (2009). Medya-siyaset-iktidar üçgeninde medya gerçeği. Selçuk Üniversitesi İletişim Fakültesi Akademik Dergisi, 6(1), 124-143, 10.18094/si.92184 http://acikerisimarsiv.selcuk.edu.tr:8080/xmlui/handle/123456789/12528 
Takvim.com.tr (2018). “Erdoğan'dan ABD’ye rahip Brunson mesaj1: 'Ver papazı al papazı'.” https://www.takvim.com.tr/video/haber-videolari/erdogandan-abdye-rahip-brunson-mesajiver-papazi-al-papazi (21.11.2018).

Torun, Ö. (2013). Disiplin toplumu ve haber söylemi: Gökkuşağı Derneği’nce yapılmış planlanan yürüyüş engellemesine ilişkin haberlerin çözümlenmesi. Gümüşhane Üniversitesi İletişim Fakültesi Elektronik Dergisi, 2(1), 106-132.

Türk Dil Kurumu Türkçe Sözlük "Dil." http://www.tdk.gov.tr/index.php?option=com_gts\&arama=gts\&guid=TDK.GTS.5be19108 db10b3.15584048 (6.11.2018).

Türk Dil Kurumu Türkçe Sözlük (2018). "Hegemonya." http://www.tdk.gov.tr/index.php?option=com_gts\&arama=gts\&guid=TDK.GTS.5be6e390 92e893.16409908 (10.11.2018).

Türk Dil Kurumu Türkçe Sözlük (2018). "İktidar." http://www.tdk.gov.tr/index.php?option=com_gts\&arama=gts\&guid=TDK.GTS.5beca86ee 249d5.40661789 (15.11.2018).

Van D. \& Teun A. (1988). News as discorse. Lawrence Erlbaum Associates.

Yaman, Y. \& Durgun, G. B. (2017). İdeoloji, dil ve sembol bağlamında medya ve siyaset. Akademik Hassasiyetler,4(7), 39-51. https://dergipark.org.tr/en/pub/akademikhassasiyetler/issue/29493/298395

Yaylagül, L. (2017). Kitle iletişim kuramları egemen ve eleştirel yaklaşımlar. Dipnot Yayınları.

Yıldız-Ekin, T. (2005). Spor basınında anlatım dili: manşet ve başlıklar. Eğitim Fakültesi Dergisi. 18(1): 93-106. https://acikerisim.uludag.edu.tr/handle/11452/11106 